\title{
V. Abkürzungen von Zeitschriften
}

Die Nummern beziehen sich auf den ausführlichen Titel der Zeitschriften and Veröffentlichungen S. XI und S. XVIII.

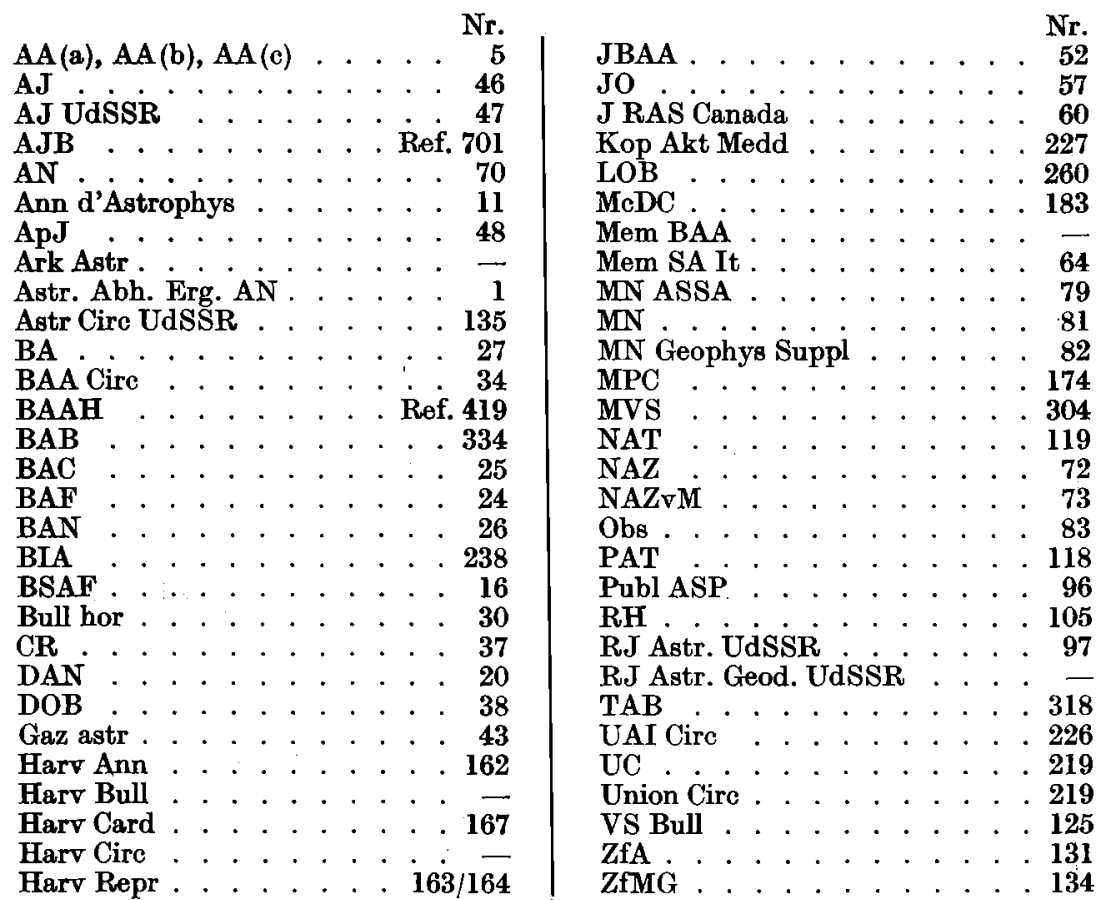

\section{Zeitschriften}

Unter Zeitschriften sind nicht nur alle periodisch erscheinenden Schriften verstanden, sondern im weiteren Sinne auch alle zwanglos erscheinenden Veröffentlichungen von Sternwarten, Instituten, Gesellschaften und Akademien.

Die vollständig durchgesehenen Zeitschriften sind in den beiden folgenden Verzeichnissen VI und VII zusammengestellt.

Einzelne Zeitschriften, die nicht direkt eingesehen werden konnten, sind dadurch kenntlich gemacht, daß in den beiden Verzeichnissen ihre laufende Nummer eingeklammert ist.

Nicht aufgeführt sind in den Verzeichnissen VI und VII diejenigen Zeitschriften, in denen gelegentlich astronomische Arbeiten enthalten sind. Diese sind der Schriftleitung entweder nur in Form eines Sonderdruckes, als einzelne Abhandlung einer Akademie oder als sonstige bibliographische Mitteilung bekannt geworden. 


\section{Verzeichnis der Zeitschriften und Veröffentlichungen von Gesellschaften und Akademien}

1. Astronomische Abhandlungen. Ergänzungshefte zu den Astronomischen Nachrichten. Akademie-Verlag, Berlin. - Band 12 Nr. 3.

2. Abhandlungen der Deutschen Akademie der Wissenschaften zu Berlin. Klasse für technische Wissenschaften. - Jahrgang 1953 Nr. 1.

3. Abhandlungen der Deutschen Akademie der Wissenschaften zu Berlin. Klasse für Mathematik und allgemeine Naturwissenschaften. - Jahrgang 1950 Nr. 6, Jahrgang 1952 Nr. 2.

4. Physics Abstracts. Section A of Science Abstracts (Physics). Edited and issued monthly by the Institution of Electrical Engineers, London. Vol. 56 Nr. $661-672$.

5. Acta Astronomica. Krakau. - AA(b) Vol. 2 S. 86-133; AA(c) Vol. 5 S. $33-56$.

6. Acta Astronomica Sinica. Herausgegeben vom Purple Mountain Observatory, Nanking. - Vol. 1 Nr. 1 (chinesisch, teilweise referiert).

7. Geochimica et Cosmochimica Acta. Pergamon Press Ltd., London. - Vol. 3 Nr. 1-6, Vol. 4 Nr. $1-6$.

8. Actas de la Academia Nacional de Ciencias Exactas, Físicas y Naturales de Lima. - Vol. 16 Nr. $1-4$.

9. Annalen der Physik. Johann Ambrosius Barth, Leipzig. - 6. Folge Band 11 Heft 4-8, Band 12 und Band 13 Heft $1-8=$ Band 446, 447 und 448 der ganzen Reihe.

10. Wissenschaftliche Annalen. Berlin, Akademie-Verlag. - 2. Jahrgang Nr. $1-12$.

11. Annales d'Astrophysique. Paris. - Tome 16 Nr. $1-6$.

12. Annales Françaises de Chronométrie. Besançon. - Année 23 Trimestre $1-4$.

13. Annales de Géophysique. Paris. - Tome 9 Nr. $1-4$.

14. Annales de Physique. Masson et Cie, Editeurs. Paris. - Sér. 12 Tome 8 Nr. $1 \rightarrow 12$.

15. Anzeiger. Österreichische Akademie der Wissenschaften. Mathematischnaturwissenschaftliche Klasse. Wien. - 90. Jahrgang Nr. 1-15.

16. L'Astronomie. Revue Mensuelle d'Astronomie, de Météorologie et de Physique du Globe. Bulletin de la Société Astronomique de France. Paris. - 67e année, Jan. -Déc. 1953.

17. Astrophysica Norvegica. Edited by the Institute of Theoretical Astrophysics, University of Oslo. - Vol. 5 Nr. 3.

18. Atti della Accademia Nazionale dei Lincei. Anno CCCXLIX, 1952. Serie Ottava. Rendiconti. Classe di Scienze fisiche, matematiche e naturali. Roma. - Vol. 14 und 15.

19. Atti della Accademia Nazionale dei Lincei. Anno CCCXLIX, 1952. Memorie. Classe di Scienze fisiche, matematiche e naturali. Roma. - Serie 8, Volume 4 . 
20. Berichte (Doklady) der Akademie der Wissenschaften der UdSSR. MoskauLeningrad. - Tom 88-93, jeweils Heft $1-6$.

21. Physikalische Berichte. Herausgegeben vom Verband Deutscher Physikalischer Gesellschaften e. V. Akademie-Verlag, Berlin. - Band 32 Heft $1-12$.

22. Physikalische Blätter. Physik Verlag, Mosbach (Baden). - 9. Jahrgang Heft 1-12.

23. Boletin de la Academia de Ciencias Fisicas, Matematicas y Naturales. Caracas. - Ano 19 - Tomo 16 Nr. 49, Tomo 17 Nr. 50.

24. Bulletin de l'Association Française d'Observateurs d'Etoiles Variables. Lyon. - Tome 12.

25. Bulletin of the Astronomical Institutes of Czechoslovakia (früher Bulletin of the Central Astronomical Institute of Czechoslovakia). Verlag der Akademie der Wissenschaften, Prag. - Vol. 4 Nr. $1-6$.

26. Bulletin of the Astronomical Institutes of the Netherlands. Haarlem. Vol. 12 Nr. $441-449$.

27. Bulletin Astronomique. Publié par l'Observatoire de Paris. — Tome 17 Fasc. 1-3.

28. Bulletin der Astronomisch-Geodätischen Gesellschaft der UdSSR. Verlag der Akademie der Wissenschaften der UdSSR. Moskau-Leningrad. Nr. $12(19), 13(20), 14(21)$.

29. Bulletin de la Classe des Sciences. Académie royale de Belgique. 5e Série. Bruxelles. - Tome 39.

30. Bulletin horaire du Bureau International de l'Heure. Observatoire de Paris. - 3me Série Nr. 7-9. Série E Nr. 7, 9.

(31). Bulletin der Kommission für Sonnenforschung. Verlag der Akademie der Wissenschaften der UdSSR, Moskau-Leningrad. - Nr. 8-9.

32. Časopis čs. ústavủ astronomických. Verlag der Akademie der Wissenschaften, Prag. - Band 3 Nr. $1-6$.

33. Ciel et Terre. Bulletin ménsuel de la Société Belge d'Astronomie, de Météorologie et de Physique du Globe. Uccle-Brüssel. - Année 69 Nr. 1 -12.

34. British Astronomical Association Circular. London. - Nr. 339-347.

35. Coelum. Periodico Bimestrale per la Divulgazione dell'Astronomia. Bologna. - Vol. 21 Nr. 1-12.

36. Sterrekundig Colloquium van de Nederlandse Astronomen-Club. Gravenhage. - Nr. 12.

37. Comptes Rendus hebdomadaires des Séances de l'Académie des Sciencos. Paris. - Tome 236 Nr. 1-26, 237 Nr. 1-25.

38. Documentation des Observateurs. Institut d'Astrophysique de Paris. 6e année Nr. $1-12$.

39. Endeavour. Eine Vierteljahres-Übersicht von Fortschritten der Wissenschaften im Dienste der Menschheit. London. - Band 12 Nr. 45-48.

40. Ergebnisse der exakten Naturwissenschaften. Springer-Verlag, GöttingenBerlin-Heidelberg. - Band 27.

41. Extraits d'Astronomie et de Géophysique du Contro National de la Recherche Scientifique. (Continuation de la Bibliographie Mensuelle de l'Astronomie) Paris. - Vol. 14 Nr. $1-12$. 
42. Forschungen und Fortschritte. Nachrichtenblatt der Deutschen Wissenschaft und Technik. Akademie-Verlag, Berlin. - Jahrgang 27 Heft $1-6$.

43. Gazette astronomique. Bulletin de la Société d'Astronomie d'Anvers. Annéo 35 Nr. 1-9 (Gesamtnummer 397-405).

44. Glasnik. Societas Scientiarum Naturalium Croatica. Periodicum Mathe: matico-Physicum et Astronomicum, Zagreb. - Ser. (2) T. 8.Nr. $1-4$.

45. Hemel en Dampkring. J. B. Wolters, Groningen. - 51. Jaargang Af. 1-12.

46. The Astronomical Journal. Yale Univ. Office, New Haven. - Vol. 58 Nr. 1-8 (Gesamtnummer 1205-1212).

47. Astronomisches Journal. Akademie der Wissenschaften der UdSSR. Moskau-Leningrad. - Tom 30 Nr. 1-6.

48. The Astrophysical Journal. Chicago. - Vol. 117 Nr. 1-3, Vol. 118 Nr. $1-3$.

49. The Irish Astronomical Journal. Armagh. - Vol. 2 Nr. 5-8.

50. The Journal of the Astronomical Society of Victoria. Melbourne. - Vol. 6 Nr. 6.

51. Journal of Atmospheric and Terrestrial Physics. Butterworth-Springer Ltd., London. - Vol. 3 Nr. 1-6, Vol. 4 Nr. $1-5$.

52. Journal of the British Astronomical Association. Oxford. - Vol. $63 \mathrm{Nr}$. $2-8$, Vol. 64 Nr. 1.

53. Journal of the British Interplanetary Society. London. - Vol. 12 Nr. $1-6$.

õ4. Journal of Calendar Reform. Published by the World Calendar Association, Inc. New York. - Vol. 23 Quarter 1 -4.

55. Journal of Geophysical Research. The continuation of Terrestrial Magnetism and Atmospheric Electricity. The William Byrd Press, Richmond. Vol. $58 \mathrm{Nr} .1 \rightarrow 4$.

56. The Journal of the Institute of Navigation. London. - Vol. 6 Nr. 1-4.

57. Journal des Observateurs. Publié avec le concours du Centre National de la Recherche Scientifique. Marseille. - Vol. 36 Nr. 1-12.

58. Journal of the Optical Society of America. Published for the Optical Society of America by American Institute of Physics. - Vol. 43 Nr. 1-12.

59. Le Journal de Physique et Le Radium. Publication de la Société Française de Physique. Paris. - Tome 14 Nr. 1-12.

60. The Journal of the Royal Astronomical Society of Canada. Toronto. Vol. 47 Nr. 1 -6 (Gesamtnummer 400-405).

61. Leaflet. Astronomical Society of the Pacific. San Francisco. - Nr. 285296.

62. Astronomical News Letter. Issued and distributed by the Harvard College Observatory, Cambridge, Mass., for the Committee for the Distribution of Astronomical Literature of the American Astronomical Society. Nr. 68-71.

63. Mededeling. Werkgroep Meteoren v.d. Ned. Vereniging voor Weer- en Sterrenkunde. - Nr. 27-31.

Memorie siehe auch Atti.

64. Memorie della Società Astronomica Italiana. Nuova Serie. Pavia. Vol. 24 Nr. $1-4$. 
65. De Meteoor. Organ van de Werkgroep Meteoren van de Nederlandse Vereniging voor Weer- en Sterrenkunde. Utrecht. - 8e Jaargang Nr. 5, ge Jaargang Nr. $1-6$.

66. Meteoritics. The Journal of the Meteoritical Society and the Institute of Meteoritics of the University of New Mexico. Albuquerque. - Vol. 1 Nr. 1 (Gesamtnummer 1).

67. Naučna Misao. Društvo ža Unapredivanje i Sirenje Nauke. Zagreb. Jahrgang 1953 Heft 1.

68. Mitteilungen der Astronomischen Gesellschaft. - 1952.

69. Mitteilungen für Planetenbeobachter. Planetensektion der Sternfreunde, Berlin. - 6. Jahrgang Nr. 1-6.

70. Astronomische Nachrichten. Im Auftrage der Deutschen Akademie der Wissenschaften zu Berlin. - Band 281 Heft 2-4.

71. Nachrichten der Akademie der Wissenschaften in Göttingen. Mathematisch-Physikalische Klasse. IIa. Mathematisch-Physikalisch-Chemische Abteilung. - Jahrgang 1953 Nr. 1-10.

72. Nachrichtenblatt der Astronomischen Zentralstelle. Astronomisches Rechen-Institut, Heidelberg. - Jahrgang 7 Nr. 1-10.

73. Nachrichtenblatt der Astronomischen Zentralstelle. Vorläufige Mitteilung. Astronomisches Rechen-Institut, Heidelberg. - Nr. 172-205.

74. Astronomischer Nachrich tendienst der Archenhold-Sternwarte zu BerlinTreptow. - 5. Jahrgang Nr. 1-24. (Wird nur auszugsweise referiert.)

75. Nature. A Weekly Journal of Science. Macmillan and Co., London; The Macmillan Company, New York. - Vol. 171 Nr. 4340-4365, Vol. 172 Nr. 4366-4391.

76. La Nature. Revue des Sciences et de leurs Applications. Masson et Cle, Editeurs, Paris. - Vol. 81 Nr. 3213 - 3224.

77. Die Naturwissenschaften. Springer-Verlag, Berlin-Göttingen-Heidelberg. - 40. Jahrgang Heft 1-12.

(78). Navigation. Los Angeles, Cal. - Vol. 3 Nr. 7-10.

79. Monthly Notes of the Astronomical Society of South Africa. Cape Town. Vol. 12 Nr. 1-11.

80. Occasional Notes. Royal Astronomical Society. London. - Vol. 3 Nr. 15.

81. Monthly Notices of the Royal Astronomical Society. London. - Vol. 113 Nr. $1-6$.

82. Monthly Notices of the Royal Astronomical Society. Geophysical Supplement. London. - Vol. 6 Nr. 7-8.

83. The Observatory. Oxford. - Vol. 73 Nr. 872-877.

84. Optik. Zeitschrift für das gesamte Gebiet der Licht- und Elektronenoptik. Stuttgart. - Band 10 Heft 1-12.

85. Orion. Zeitschrift der Schweizerischen Astronomischen Gesellschaft. Bulletin de la Société Astronomique de Suisse. Genève bzw. Schaffhausen. Band 4 Nr. 38-41.

86. Photographie und Forschung. Die Contax-Photographie in der Wissenschaft. Hausmitteilungen der Zeiss Ikon AG., Stuttgart. - Band 5 Heft $5-8$. 
87. Photographie und Wissenschaft. Agfa-Mitteilungen für wissenschaftliche Institute und Forschungsstätten. Agfa-Leverkusen, Bayerwerk. - Jahrgang 2 Heft $1-3$.

88. Physica. Herausgegeben von der Stiftung Physica in Amsterdam. - Deel 19 Nr. 1-12.

89. Postepy Astronomii. Czasopismo pošwięcone upowszechnianiu wiedzy astronomicznej. Kraków. - Tom 1 Nr. 1-2.

90. Priroda (Natur). Populäres naturwissenschaftliches Journal der Akademie der Wissenschaften der UdSSR. Moskau-Leningrad. - Tom 42 Nr. 1-12.

91. Proceedings of the National Academy of Sciences of the United States of America. Washington. - Vol. 39 Nr. 1-12.

92. The Proceedings of the Physical Society. Section A, Section B. London. Vol. 66 Part 1-12.

93. Proceedings of the Royal Society. Series A. Mathematical and Physical Sciences. London. - Vol. 216-220 Nr. 1124-1143.

94. Proceedings of the Section of Sciences. Koninklijke Nederlandse Akademie van Wetenschappen. Series B. Physical Sciences. Amsterdam. - Vol. 56.

95. Publications of the Astronomical Society of Japan. Tokyo. - Vol. 4 Nr. 4, Vol. 5 Nr. $1-2$.

96. Publications of the Astronomical Society of the Pacific. San Francisco. - Vol. 65 Nr. $382-387$.

Rendiconti siehe Atti.

97. Referatjournal. Astronomie. Akademie der Wissenschaften der UdSSR. Institut für wissenschaftliche Information. Verlag Akad. Wiss. UdSSR, Moskau. - 1953 Nr. 1-3.

98. Annual Report of the Board of Regents of The Smithsonian Institution showing the operations, expenditures, and condition of the Institution for the year ended June 30, 1952 = Publication 4111.

99. The Science Reports of the Tôhoku University. First Series (Physics, Chemistry, Astronomy). Sendai, Japan. - Vol. 37 Nr. $1-4$.

(100). Hydrographic Review. (Erscheint auch als Revue Hydrographique, Monte Carlo, Monaco). - Vol. 30 Nr. 1-2.

101. The Physical Review. Series 2. Published for the American Physical Society by the American Institute of Physics. Lancaster Pa., and New York, N.Y. - Vol. 89-92, je 6 Hefte.

102. The Review of Scientific Instruments, Now Series. Published monthly by the American Institute of Physics. Lancaster, Pa., and New York, N. Y. - Vol. 24 Nr. 1-12.

103. Mathematical Reviews. Published by the American Mathematical Society, Lancaster, Penn. - Vol. 14 Nr. 1-11.

104. Reviews of Modern Physics. Published for the American Physical Society by the American Institute of Physics. Lancaster and New York. Vol. 25 Nr. $1-4$.

105. Ŕíše h vèzd. Herausgegeben vom Ministerium für Kultur und der Tschechoslowakischen Astronomischen Gesellschaft im Verlag Orbis, Prag. Band 34 Nr. 1-10 (tschechisch, Inhalt auch in russischer und englischer Sprache). 
106. Matematicko-př́rodovědecké rozhledy. Verlag der Akademie der Wiseenschaften, Prag. - Band 32 Nr. $1-6$.

107. Naturwissenschaftliche Rundschau. Wissenschaftliche Verlagsgesellschaft m. b. H., Stuttgart. - Jahrgang 6 Heft 1-12.

108. Scientia. Internationale Zeitschrift für wissenschaftliche Synthese. Bologna. - Vol. 88 Nr. 1-12.

109. Service de Prévision Ionosphérique Militaire. Station de Fribourg. Septembre-Décembre 1952. SPIM - O - 75 F -78 F.

110. Sitzungsberichte der Deutschen Akademie der Wissenschaften zu Berlin. Klasse für Mathematik und allgemeine Naturwissenschaften. AkademieVerlag, Berlin. - Jahrgang 1952 Nr. 5, Jahrgang 1953 Nr. $1-2$.

111. Sitzungsberichte der mathematisch-naturwissenschaftlichen Klasse der Bayerischen Akademie der Wissenschaften zu München. - Jahrgang 1952.

112. Sitzungsberichte. Österreichische Akademie der Wissenschaften. Mathematisch-naturwissenschaftliche Klasse, Abteilung IIa. Wien. - Band 162 Heft 1-10.

113. Sky and Telescope. Harvard College Observatory, Cambridge, Mass. Vol. 12 Nr. 3-12, Vol. 13 Nr. l-2.

114. Southern Stars. The Journal of the Royal Astronomical Society of New Zealand. - Vol. 15 Nr. 8-9 (Gesamtnummer 112-113).

115. Die Sterne. Monatsschrift über alle Gebiete der Himmelskunde. Verlag Johann Ambrosius Barth, Leipzig. - 29. Jahrgang Heft 1-12.

116. Sternenwelt. Populäre Zeitschrift für Astronomie und ihre Geschichte. Manz-Verlag, Abt. Sternenwelt. München. - 5. Jahrgang Heft 1-10. Erscheinen eingestellt.

117. The Strolling Astronomer. Association of Lunar and Planetary Observers. Las Cruces, New Mexico. - Vol. 7 Nr. 1-12.

118. Populär Astronomisk Tidskrift. Stockholm. - Árgång 34 Hăfte 1-4.

119. Nordisk Astronomisk Tidsskrift. Kopenhagen. - $1953 \mathrm{Nr} .1-4$.

(120). Universitas. Zeitschrift für Wissenschaft, Kunst und Literatur. Stuttgart. - Jahrgang 8.

121. Urania. Revista de Astronomia y Ciencias Afines. Organo Oficial de la Sociedad Astronómica de España y América y de la Unión Nacional de Astronomía y Ciencias Afines. Barcelona. - Ãno 38 Nr. 233-235.

122. Urania. Populært astronomisk Tidsskrift. Kopenhagen. - Aargang 10 Nr. 1-12.

123. Urania. Czasopismo astronomiczne popularno-naukowe. Organ Polskiego Towarzystwa Milośników Astronomii. Kraków. - Rok 24 Nr. 1-12.

124. Vega. An International Monthly Review of Astronomical Research. Boughton, Chester. - Vol. 1 Nr. 1-11.

125. Veränderliche Sterne. Bulletin, herausgegeben vom Astronomischen Rat der Akademie der Wissenschaften der UdSSR. Moskau-Leningrad. Tom 9 Nr. 3-5 (81-83).

126. Physikalische Verhandlungen. Physik Verlag, Mosbach (Baden). 4. Jahrgang Heft 1-8.

127. Vesmír. Verlag der Akademie der Wissenschaften, Prag. - Band 32 Nr. $1-10$. 
128. Vierteljahrsschrift,der Naturforschenden Gesellschaft Zürich. Verlag Gebr. Fretz AG., Zürich. - Jahrgang 98 Heft 1-4.

129. Weltraumfahrt. Beiträge zur Weltraumforschung und Astronautik. Umschau-Verlag, Frankfurt am Main. - Jahrgang 1953 Heft $1-4$.

130. Deutsche Hydrographische Zeitschrift. Deutsches Hydrographisches Institut Hamburg. - Band 6 Heft $1-6$.

131. Zeitschrift für Astrophysik. Springer-Verlag, Berlin-Göttingen-Heidelberg. - Band 31 Heft 4, Band 32 Heft 1-4, Band 33 Heft $1-3$.

132. Zeitschrift für Naturforschung. Verlag der Zeitschrift für Naturforschung, Tübingen. - Band 8a Heft 1-12.

133. Zeitschrift für Physik. Springer-Verlag, Berlin-Göttingen-Heidelberg. Band 133 Heft 1-5, Band 134 Heft $1-5$, Band 135 Heft 1-5.

134. Zentralblatt für Mathematik und ihre Grenzgebiete. Springer-Verlag, Berlin-Göttingen-Heidelberg. - Band 45 Heft 4-6, Band 46 Heft 1-10, Band 47 Heft $1-10$, Band 48 Heft $1-10$.

135. Astronomisches Zirkular. Herausgegeben vom Büro der Astronomischen Mitteilungen der Akademie der Wissenschaften der UdSSR. Kasan. Nr. 133-144. 


\section{Verzeichnis der Veröffentlichungen von Sternwarten und Instituten}

Die in der folgenden Tabelle genannten Sternwarten sind in dem Verzeichnis der Veröffentlichungen von Sternwarten und Instituten unter dem Ort (rechte Spalte der Tabelle) aufgeführt.

\begin{tabular}{|c|c|}
\hline Name der Sternwarte & Ort \\
\hline $\begin{array}{l}\text { Agassiz Station } \\
\text { Allegheny Observatory } \\
\text { University of California } \\
\text { Carter Observatory } \\
\text { Observatorio de Cartuja } \\
\text { Commonwealth Observatory } \\
\text { Commonwealth Scientific and Industrial Research } \\
\text { Organization, Australia } \\
\text { Dearborn Observatory of Northwestern University } \\
\text { Dominion Observatory } \\
\text { Dominion Astrophysical Observatory } \\
\text { David Dunlap Observatory, University of Toronto } \\
\text { Dunsink Observatory } \\
\text { Observatorio del Ebro } \\
\text { Engelhardt-Observatorium } \\
\text { Observatorio Fabra } \\
\text { Flower Astronomical Observatory } \\
\text { Fraunhofer-Institut } \\
\text { Harvard College Observatory } \\
\text { Kapteyn Astronomical Laboratory } \\
\text { Kwasan Observatory } \\
\text { Lick Observatory } \\
\text { Goethe Link Observatory of Indiana University } \\
\text { Lowell Observatory } \\
\text { Leander McCormick Observatory of the University } \\
\text { of Virginia } \\
\text { McDonald Observatory } \\
\text { McMath-Hulbert Observatory } \\
\text { Observatory of the University of Michigan } \\
\text { Astronomical Observatory, University of Minnesota } \\
\text { Nizamia Observatory } \\
\text { University of Pennsylvania } \\
\text { Perkins Observatory } \\
\text { Radcliffe Observatory } \\
\text { Remeis-Sternwarte } \\
\text { Rutherfurd Observatory } \\
\text { Smithsonian Institution } \\
\text { Specola Astronomica Vaticana } \\
\text { Sproul Observatory } \\
\text { Staatliches Astronomisches Sternberg-Institut }\end{array}$ & $\begin{array}{l}\text { Oak Ridge } \\
\text { Pittsburgh } \\
\text { Los Angeles } \\
\text { Wellington, N. Z. } \\
\text { Granada } \\
\text { Canberra } \\
\text { Sydney } \\
\text { Evanston, Ill. } \\
\text { Ottawa } \\
\text { Victoria, Canada } \\
\text { Richmond Hill } \\
\text { Dublin } \\
\text { Tortosa } \\
\text { Kasan } \\
\text { Barcelona } \\
\text { Upper Darby, Penn. } \\
\text { Freiburg i. Br. } \\
\text { Cambridge, Mass. } \\
\text { Groningen } \\
\text { Kyoto } \\
\text { Mount Hamilton } \\
\text { Bloomington } \\
\text { Flagstaff, Ariz. } \\
\text { Charlottesville } \\
\text { Fort Davis, Tex. } \\
\text { Lake Angelus, } \\
\text { Pontiac, Mich. } \\
\text { Ann Arbor } \\
\text { Minneapolis } \\
\text { Hyderabad } \\
\text { Philadelphia } \\
\text { Delaware, Ohio } \\
\text { Pretoria } \\
\text { Bamberg } \\
\text { New York } \\
\text { Washington } \\
\text { Castel Gandolfo } \\
\text { Swarthmore, Penn. } \\
\text { Moskau }\end{array}$ \\
\hline
\end{tabular}




\begin{tabular}{l|l}
\hline \multicolumn{1}{c|}{ Na me der Sternwarte } & \multicolumn{1}{c}{ Ort } \\
\hline $\begin{array}{l}\text { Astronomisches Hauptobservatorium der Akademie } \\
\text { der Wissenschaften der Ukrainischen Sowjet- }\end{array}$ & \\
republik & Golossejewo \\
Union Observatory & Johannesburg \\
United States Naval Observatory & Washington \\
Vassar College Observatory & $\begin{array}{l}\text { Poughkeepsie, N. Y. } \\
\text { Warner and Swasey Observatory }\end{array}$ \\
Washburn Observatory of the University of Wisconsin , Ohio \\
Astronomical Observatory of Yale University & Madison \\
Yerkes Observatory & New Haven, Conn. \\
& Williams Bay, Wis.
\end{tabular}

\section{Abastumani}

136. Bulletin des Astrophysikalischen Observatoriums Abastumani auf dem Kanobili.

Nr. 13: M. A. Waschakidse, Untersuchung der galaktischen Absorption des Lichts aus den Farbenexzessen außergalaktischer Nebel und langperiodischer Cepheiden und nach anderen Methoden. Ref. 12523.

14: W. B. Nikonow, Versuch der Aufstellung eines Fundamentalkatalogs photoelektrischer Farbäquivalente von B8- und B9Sternen. Ref. 9413.

15: N. L. Magalaschwili, Elektrophotometrie der Bedeckungsveränderlichen RX Herculis und RS Vulpeculae. Ref. 11120. R. A. Bartaja, Untersuchung der am Observatorium Abastumani entdeckten Nova CT Serpentis. Ref. 11344.

R. A. Bartaja, Bestimmung der spektroskopischen absoluten Größen schwacher B5- bis A7-Sterne. Ref. 9701.

A. F. Torondshadse, Besonderheiten der Bewegungen der $\mathrm{O}$. und B-Sterne und die Ausdehnung der Sternassoziationen. Ref. 12351.

S. M. Tachohaidse, N. I. Georgobiani, Spektrohelioskopische Beobachtungen auf dem Kanobili 1941-1944. Ref. 665l. Chronik. Nicht referiert.

Verzeichnis der Arbeiten und Autoren zu den Bulletins des Astrophysikalischen Observatoriums Abastumani Nr. 1-15 (19371953). Ref. 721.

\section{Alger}

137. Publications de l'Observatoire d'Alger.

L. Boyer, La planète 173 Ino. Ref. 7536.

\section{Amsterdam}

138. Publications of the Astronomical Institute of the University of Amsterdam.

Nr. 10: D. Koelbloed, Line spectra of some giant and dwarf K-type stars. Ref. 9532.

139. Circular of the Astronomical Institute of the University of Amsterdam.

Nr. 7: A.van Pelt, On the spectrum of planetary nebulae having Wolf.Rayet nuclei. Ref. 12228. 


\section{Arcetri}

140. Osservazioni e Memorie dell'Osservatorio Astrofisico di Arcetri.

Nr. 68: G. Abetti, Premessa. Nicht referiert.

A. Colacevich, M. G. Fracastoro, Risultati preliminari sul sistema di 32 Cygni. Vgl. AJB 52 Ref. 11106.

M. Hack, Ricerche spettrofotometriche su $\delta$ Scuti. Vgl. AJB 62 Ref. 11155.

G. Abetti, M. Hack, Osservazioni di protuberanze e della cromosfera solare eseguite nel 1951. Vgl. AJB 52 Ref. 6601.

M. C. Ballario, Brillamenti cromosferici osservati alla torre solare di Arcetri nel 1951. Vgl. AJB 52 Ref. 6654.

M. N. Viaro, Ricerche fotometriche sulla variabile FM Aquilae. Vgl. AJB 52 Ref. 11173.

G. Righini, M. C. Ballario, G. Godoli, Determinazione dell'oscuramento al bordo durante l'eclisse parziale di Sole dell' 1-9-1951. Ref. 6209.

M. Hack, Studio spettrofotometrico di 55 Cygni. Ref. 9521.

M. G. Fracastoro, M. L. Bruni, Ricerche sulla struttura della galassia. I. Conteggi stellari nella regione attorno all'area scelta 23. Ref. 12305.

M. Hack, Confronto fra un prisma-obbiettivo ed uno spettrografo nell'analisi quantitativa delle atmosfere delle stelle di tipo O, B. Ref. 9522.

\section{Århus}

141. Meddelelser fra Ole Rømer-Observatoriet i Arhus.

Nr. 23: A. V. Nielsen, The path and orbit of the Arhus meteorites. Ref. 8346.

\section{Armagh}

142. Contributions from the Armagh Observatory.

Nr. 9: E. J. Ôpik, A climatological and astronomical interpretation of the ice ages and of the past variations of terrestrial climate. Ref. 7218 .

10: E. B. Armstrong, A note on the use of the Fabry-Perot etalon for upper atmosphere temperature measurements. Ref. 7230 .

143. Armagh Observatory Leaflet.

Nr. 16: E. M. Lindsay, Armagh Observatory in 1952. Ref. 1101.

17: E. M. Lindsay, The ADH (Armagh-Dunsink-Harvard) telescope. Ref. 1206.

18: E. B. Armstrong, Electron image-forming devices in astronomy. Ref. 2202.

19: E. J. Öpik, On the causes of palaeoclimatic variations and of the ice ages in particular. Ref. 7220.

20: E. J. Ópik, A vibrating camera for meteor photography. Ref. 2129.

21: E. M. Lindsay, A possible old supernova in the Large Magellanic Cloud. Ref. 11349.

22: E. J. Ópik, Stellar associations and supernovae. Ref. 5418.

\section{Asiago}

144. Contributi dell'Osservatorio Astrofisico dell'Università di Padova in Asiago.

Nr. 27: G. Righini, G. Mannino, Ricerche spettrofotometriche sulle stelle Be. II. Studio della stella $\psi$ Persei. Vgl. AJB 52 Ref. 9554. 
28: G. Righini, G. Mannino, Ricerche spettrofotometriche sulle stelle Be. III. Studio della stella $\beta$ Monocerotis A. Vgl. AJB 52 Ref. 9555.

29: G. Mannino, Ricerche spettrofotometriche sulle stelle Be. IV. Studio della stella e Persei. Vgl. AJB 52 Ref. 9538.

30: G. Mannino, Ricerche spettrofotometriche sulle variabili del tipo $\beta$ Canis Majoris. II. Lo spettro della stella $\eta$ Aurigae. Vgl. AJB 52 Ref. 9537.

31: G. de Strobel, Profili e larghezze equivalenti di alcune righe di Sirio fra $\lambda 4000-4600$. Vgl. AJB 52 Ref. 9563.

32: S. Taffara, Determinazioni di larghezze equivalenti nello spettro di Procione. Ref. 9568.

33: S. Taffara, Fotometria fotografica delle regioni stellari: Perseo (con centro $\alpha 19004^{\mathrm{h}} 7^{\mathrm{m}} \delta 1900+32^{\circ} 0^{\prime}$ ), regione polare Nord, selected area n. 49. Ref. 9422.

34: G. Mannino, Grandezze fotografiche della variabile IU Cygni. Ref. 11156.

35: G. Righini, G. de Strobel, Ricerche spettrofotometriche sulle stelle Be. V. Studio della stella 66 Ophiuci. Ref. 9554.

36: G. Mannino, Ricerche spettrofotometriche sulle stelle Be. VI. Lo spettro della stella k Cassiopeiae. Ref. 9535.

37: G. Mannino, Spettrofotometria della stella $\delta$ Persei (gB5). Ref. 9536.

38: G. Mannino, Ricerche spettrofotometriche sulle variabili del tipo $\beta$ Canis Majoris. III. Lo spettro della stella $\eta$ Lyrae. Ref. 9537.

39: R. Cayrel, S. Taffara, Relation largeur equivalente - profondeur centrale pour des raies d'absorption. Formulation analytique de la relation et comparaison avec l'observation. Ref. 9515.

40: G. Mannino, Lo spettrosensitometro dell'Osservatorio Astrofisico di Asiago. Ref. 1204.

41: G. de Strobel, Ricerche spettrofotometriche sulle stelle Be. VII. Studio della stella $\Theta$ Coronae Borealis. Ref. 9560.

42: G. de Strobel, Ricerche spettrofotometriche sulle stelle Be. VIII. Studio della stella 12 Vulpeculae. Ref. 9561.

\section{Belgrad}

145. Académie Serbe des Sciences. Bulletin de l'Observatoire Astronomique de Beograd.

17 1-_2: M. Protitch, Observations photographiques de la comète 1939a (Kozik-Peltier) faites à l'astrographe de $160 \mathrm{~mm}$. Ref. 8141 .

L. Mitić, Z. Petović, B. Ševarlić, Observations à la lunette zénithale (de $110 \mathrm{~mm}$ ) du Service de latitude de l'Observatoire, faites au cours des deux premiers trimestres de 1952. Ref. 13218. V. Oskanjan, Déterminations visuelles de l'extinction à l'Observatoire de Belgrade. Ref. 7268.

Occultations d'étoiles par la Lune observées en 1952. Ref. 7360. M. Protitch, U. Živanović, O. Kovačević, Activité des taches solaires au cours de l'année 1952. Ref. 6370.

B. Popović, Orbites des petites planètes $1950 \mathrm{PD}, 1950 \mathrm{PE}$, 1951 AJ (AQ) et 1951 AL. $\$ 75$.

B. Popović, Orbites circulaires des petites planètes. § 75.

3-4: M. Protitch, Observations photographiques de petites planètes faites à l'astrographe de $160 \mathrm{~mm}$. $\$ 75$.

M. Protitch, Observations photographiques de comètes $1951 \mathrm{i}$ 
Wilson-Harrington, 19511 Schaumasse, $1952 \mathrm{~d}$ Peltier, faites à l'astrographe de $160 \mathrm{~mm}$. $\$ 81$.

V. Oskanjan, Une nouvelle variable près de l'étoile UV Ceti. Ref. 11210.

Z. Petović, B. Sevarlić, Observations à la lunette zónithale de $110 \mathrm{~mm}$ du Service de latitude de l'Observatoire, faites au cours des deux derniers trimestres de 1952. Ref. 13221.

Z. Brkić, Anomalies locales dans l'inclinaison de l'axe de la lunette méridienne. Ref. 2105.

P. Djurković, Mesures micrométriques d'étoiles doubles, faites en 1952 au réfracteur de $0.65 \mathrm{~m}$ d'ouverture. Ref. 10128.

Predictions for 1955 of occultations of stars by the moon visible at Belgrade. Ref. 7358.

M. Protitch, Observations des éclipses partielles de Lune et de Soleil, observées au cours de 1952. Ref. 7349, 6210, 7350.

V.V. Michkovitch, Rapport annuel sur l'état et l'activité de l'Observatoire en 1952. Ref. 1101.

18 1-2: P. M. Djurković, Mesures micrométriques d'étoiles doubles. Ref. 10128.

M. Protitch, Č. Cepinac, Observations photographiques des petites planètes. $\S 75$.

M. Protitch, Observations photographiques de la comète 1953 a (Mrkos-Honda). Ref. 8161.

Z. Petović, D. Saletić, B. Ševarlić, R. Vojčć, Observations à la lunette zénithale (de $110 \mathrm{~mm}$ ) du Service de latitude de l'Observatoire, faites au cours des deux premiers trimestres de 1953. Ref. 13222.

Occultations d'étoiles par la Lune. Ref. 7360.

P. M. Djurković, Champs d'activité de taches solaires. Ref. 6311.

B. Popović, Eléments de la comète 1953a-Mrkos-Honda. Ref. 8161.

B. Popović, Eléments et éphémérides des petites planètes 1950 FC, 1950 RB, 1952 SA. § 75.

V. Oskanjan, Variations d'éclat de l'étoile UV Ceti. Ref. 11216.

M. Protitch, U. ̌̌ivanović, O. Kovačević, Activité des taches solaires au cours du premier semestre 1953. Ref. 6370.

B. Popovié, Nouveaux éléments de 1952 EA. $\S 75$.

3-4: P. M. Djurković, Mesures micrométriques d'étoiles doubles. Ref. 10128.

Ocoultations d'étoiles par la Lune. Ref. 7360.

M. Protitch, ¿. Cepinac, Observations photographiques des petites planètes. $\S 75$.

Predictions for 1956 of occultations of stars by the moon visible at Belgrade. Ref. 7358.

V. Oskanjan, Observations de XX Cygni. § 112.

M. Protitch, U. ̌̇ivanović, O. Kovačević, Activité des taches solaires au cours du second semestre 1953. Ref. 6370.

P. M. Djurković, L'influence de la réfraction sur la valeur du tour de la vis micrométrique déduite des observations de passages. Ref. 2211.

V.V. Michkovitch, Rapport annuel sur l'état et l'activité de l'Observatoire en 1953. Ref. 1101.

146. Nautički Godišnjak za 1954. Ref. 401.

Bergedorf. Siehe Hamburg. 


\section{Berkeley}

147. Berkeley Reprint.

Nr. 34: S.-S. Huang, The variational method for problems of radiative transfer. I. Isotropic scattering with a constant net flux. Ref. 5115 .

S.-S. Huang, The variational method for problems of radiative transfer. II. The formation of absorption lines in the MilneEddington model. Ref. 5116.

S.-S. Huang, The variational method for problems of radiative transfer. III. Reflection effect. Ref. 5117.

35: R. D. Levee, A gravitationally contracting stellar model. Ref. 5216.

36: O. Struve, S. M. Kung, The F-Type component of Capella. Ref. 10205.

37: Vgl. AJB 52 Ref. 9566.

38: M. F. Walker, Photoelectric observations of HD 199908. Ref. 11216.

39: R. P. Kraft, Photoelectric observations of HD 199140. Ref. 11216.

40: O. Struve, Notes on stellar spectra. Ref. 11136.

41: H. F. Weaver, Magnitude, color, and spectral-type relations in the galactic cluster M 39. Ref. 12125 .

42: H. F. Weaver, Regional variations in the velocity dispersion of early B-type stars. Ref. 12342.

43: D. H. McNamara, Gamma Pegasi: A Beta Canis Majoris star of small velocity amplitude. Ref. 11193.

44: R. P. Kraft, The period-density relation in classical cepheids. Ref. 11152.

45: D. H. McNamara, Possibilities of a period-spectrum relation for stars of the Beta Canis Majoris class. Ref. 11194.

46: O. Struve, D. H. MoNamara, S. M. Kung, C. Beymer, Beta Cephei. Ref. 111107.

47: J. A. Crawford, Stars with helium energy sources. Ref. 5204.

48: O. Struve, Notes on stellar spectra. Ref. 9562.

49: S.-S. Huang, A statistical study of the rotation of the stars. Ref. 9806.

50: O. Struve, The radial velocity of Gamma Orionis. Ref. 9226. 0 . Struve, Variable line widths in the spectrum of Delta Scuti. Ref. 111108.

51: A. D. Williams, Color variability of Delta Scuti. Ref. 111114.

52: H. F. Weaver, B stars and spiral structure in the larger neighborhood of the sun. Ref. 12819 .

53: Vgl. AJB 52 Ref. 8165.

54: S.-S. Huang, O. Struve, A study of line profiles: the spectrum of Rho Leonis. Ref. 9528.

55: M. F. Walker, The light-variations of HD 217050 . Ref.111112.

56: S.-S. Huang, Pulsations of a rotating star. Ref. 9805.

57: D. H. McNamara, Periods and absolute magnitudes of the Beta Canis Majoris stars. Ref. 11195.

\section{Berlin}

148. Berliner Astronomisches Jahrbuch für 1955. 180. Jahrgang. Herausgeber: Astronomisches Rechen-Institut der Deutschen Akademie der Wissenschaften zu Berlin und Astronomisches Recheninstitut zu Heidelberg. Ref. 402. 
149. Deutsche Akademio der Wissenschaften zu Berlin. Veröffentlichungen des Astronomischen Recheninstituts.

E. E. Kühne, Tafel für $r^{-3}$ mit dem Argument $r^{2}\left(r^{2}\right.$ von $1-100)$. Ref. 4004.

150. Mitteilungen der Archenhold-Sternwarte Berlin-Treptow.

Nr. 29: E. Mädlow, Noch einmal: Krise der Amateur-Planetenbeobachtung? Ref. 7019.

30: D. Wattenberg, Jahresbericht der Archenhold-Sternwarte 1952. Ref. 1289.

31: D. Wattenberg, Ort und Postnova von B Cassiopeiae 1572. Ref. 11319.

32: G. Schirdewahn, Bericht über die Auswertung von Sonnenbeobachtungen 1952. Ref. 6356 .

33: D. Wattenberg, Die Kinematografie in der Astronomie. Ref. 2854.

34: E. Mädlow, H. Mielke, Auswertung von Schattenantrittsbeobachtungen bei der totalen Mondfinsternis vom 29./30. Januar 1953. Ref. 7351 .

35: H. Mielke, Umgebungskarten von Bedeckungsveränderlichen. Serie I. Ref. 11206.

151. Astronomischer Nachrichtendienst der Archenhold-Sternwarte zu BerlinTreptow. 5. Jahrgang Nr. $1-24$.

152. Wilhelm-Foerster-Sternwarte. Veröffentlichung.

Nr. 4: Tätigkeitsbericht 1951/52. Ref. 1289.

\section{Bjurakan}

153. Mitteilungen (Soobschtschenija) des Observatoriums Bjurakan.

Nr. 11: B. E. Markarjan, Die Sternassoziation Cepheus II. Ref. 12348. B. E. Markarjan, Utber die Expansion des offenen Sternhaufens IC 2602 . Ref. 12113.

\section{Bloomington}

154. Publications of the Goethe Link Observatory of Indiana University.

Nr. 10: A. N. Cox, The transfer of the north polar standards to the southern hemisphere. Ref. 9406.

11: A. N. Cox, K. L. Hallam, Photoelectric magnitude sequences for the Magellanic Clouds. Ref. 12404.

155. Goethe Link Observatory of Indiana University. Reprint.

Nr. 6: J. B. Irwin, An astronomical mystery story: The case of the missing pulsators. Ref. 12003.

7: R. R. Brownlee, A. N. Cox, Photoelectric magnitudes and colors in NGC 6231. Ref. 12103.

\section{Bologna}

156. Pubblicazioni dell'Osservatorio astronomico universitario di Bologna.

6 1: L. Rosino, Orientamenti e problemi nello studio degli ammassi globulari di stelle. Ref. 12135.

2: L. Rosino, Ricerche sugli ammassi globulari. IX. Osservazioni fotografiche di variabili e determinazione dei periodi e curve di luce di 16 Cefeidi appartenenti all'ammasso globulare M 72. Ref. 12137.

G. Horn-d'Arturo, Mitologia delle costellazioni. Ref. 615. 
3: L. Rosino, La nebulosa gassosa NGC 7635 in Cassiopea. Ref. 12231.

\section{Bonn}

157. Veröffentlichungen der Universitäts-Sternwarte zu Bonn.

Nr. 40: K.W. Schrick, Die Eigenbewegung der Praesepe. Ref. 12119.

\section{Bordeaux}

158. Publications de l'Observatoire de l'Université de Bordeaux (Floirac). Nouvelle Série.

Nr. 12: Vgl. AJB 54.

13: M. Mendes, Systèmes d'équations intégrales et figures dérivées des ellipsoìdes hétérogènes en rotation. Ref. 111.

159. Rapport présenté au Conseil de l'Université. Année scolaire $1951 \rightarrow 1952$, 1952-1953. Ref. 1101.

Breslau. Siehe Wrocław.

\section{Bruxelles}

160. Université de Bruxelles. Institut d'Astronomie.

(2) Nr. 83: J. F. Cox, Notice sur Georges Lecointe, membre de l'Académie. Ref. 1007.

84: F. H. van den Dungen, J. F. Cox, J. van Mieghem, L'effet sur la position de l'axe instantané de rotation de la Terre d'échanges de quantités de mouvement entre l'atmosphère et le globe. Ref. 13106.

85: F. H. van den Dungen, J. F. Cox, J. van Mieghem, Sur des variations du niveau des mers et de la vitesse de rotation de la Terre. Ref. 13107.

86: P. J. Melchior, Sur le déplacement des pôles d'inertie à la surface de la Terre, de 1900 à 1950 . Ref. 13119.

87: J. Brouet, P. Janssens, Sur des mesures de déplacements par rapport à la verticale d'une masse en mouvement contrôlé uniformément ralenti. Ref. 13103.

88: F. H. van den Dungen, J. F. Cox, J. van Mieghem, Sur les déplacements par rapport aux étoiles de l'axe de rotation instantané de la lithosphère, sous la sollicitation des vents méridiens. Ref. 13108.

89: J. Lemmens, Déterminations de latitude à l'aide d'un réfracteur zénithal visuel. Ref. 13214.

90: E. Schatzman, Une nouvelle théorie de la granulation solaire. Ref. 6112.

Cambridge, Engl.

161. University of Cambridge. Report of the Observatories Syndicate for the year ending 1953 September 30. Ref. 1101.

Cambridge, Mass.

162. Annals of Harvard College Observatory.

113 2: S. Gaposchkin, The eclipsing variables. Ref. 11106.

119 2: D. Hoffleit, A preliminary survey of nebulosities and associated B-stars in Carina. Ref. 12218. 
163. Harvard Reprint.

Nr. 368: H. Shapley, V. McKibben Nail, Magellanic Clouds, V. Fifty eclipsing stars. Ref. 12426.

369-371: Vgl. AJB 52.

372: H. Shapley, Magellanic Clouds, VI. Revised distances and luminosities. Ref. 12427.

373: V. MeKibben Nail, H. Shapley, Magellanic Clouds, VII. Star colors and luminosities in five constellations. Ref. 12417.

374: F. L. Whipple, On the icy conglomerate model for comets. Ref. 8034.

375: H. Shapley, Report on programmes of galactic measurement. Ref. 1375.

376: H. Shapley, Magellanic Clouds. VIII. On the population characteristics of the two Clouds. Ref. 12428.

377: V. McKibben Nail, C. A. Whitney, C. M. Wade, Magellanic Clouds. IX. The nebulosities of the Small Cloud. Ref. 12418.

378: R. N. Thomas, W. C. White, The physical theory of meteors. IV. Inquiry into the radiation problem - a laboratory model. Ref. 8234.

379: G. G. Cillié jr., E. M. Lindsay, The photoelectric light curve of V 525 Sagittarii. Ref. 1110I.

380: D. H. Menzel, B. Bell, The variation in prominence distribution over the sunspot cycle. Ref. 6630.

381: D. H. Menzel, J.W. Evans, The behavior and classification of solar prominences. Ref. 6629 .

382-389: Vgl. AJB 54.

390: M. W. Mayall, Variable star notes. Ref. 11204.

164. Harvard Reprint Series II.

Nr. 47: F. W. Wright, F. L. Whipple, The photographic Perseid meteors. Ref. 8261 .

48: S. El-Din Hamid, F. L. Whipple, On the motions of 64 longperiod comets. Ref. 8105.

49: H. Zirin, The exchange potential in an electron gas at nonzero temperature. Ref. 250.

50: H. Shapley, Note on the distribution of RR Lyrae variables. Ref. 11163.

51: S. L. Lippincott, D. Hoffleit, Note on the distribution of B5 stars. Ref. 12307.

52: F. L. Whipple, Winds in the upper atmosphere by meteortrain photography. Ref. 8237.

165. Harvard College Observatory. The American Association of Variable Star Observers. Quarterly Report.

Nr. 16-17: M. W. Mayall, Observations of variable stars. Ref. 11216, $\$ 113$.

166. Annual Report of the Director of the Astronomical Observatory of Harvard College for the year ending September 30, 1952. Ref. 1101.

167. Harvard College Observatory. Announcement Card 1202-1236.

\section{Canberra}

168. Commonwealth Observatory. Sonderdrucke.

R. v. d. R. Woolley, The solar corona. Ref. 6733.

C. W. Allen, C. S. Gum, Survey of galactic radio-noise at $200 \mathrm{Mc} / \mathrm{s}$. Ref. 12601.

R. v. d. R. Woolley, Astrophysics at the Australian University. Ref. 1270. 
R. v. d. R. Woolley, The far ultraviolet solar spectrum of the quiet sun as it affects the ionosphere. Ref. 6435 .

A. R. Hogg, Astronomical developments in Australia. Ref. 1370.

169. Report of the Commonwealth Astronomer for the year 1952. Ref. 1101.

Cape

170. First Cape Catalogue of Stars for the Equinox of 1950.0. Catalogue of 5070 Fundamental and Boss Stars compiled from Observations made with the Reversible Transit Circle at the Royal Observatory, Cape of Good Hope in the Years 1936-1944. Ref. 9122.

171. Report of Her Majesty's Astronomer at the Cape of Good Hope to the Secretary of the Admiralty for the year 1952. Ref. 1101 .

Capodimonte. Siehe Napoli.

Castel Gandolio

172. Specola Astronomica Vaticana. Ricerche Astronomiche.

3 1: W. J. Miller, Five new Cygnus-cloud variables, VV 11-15. Ref. 11207.

\section{Catania}

(173). Osservatorio Astrofisico Catania. Contributi Astrofisici.

Nr. 75: E. de Caro, Espressione generale della velocità areolare nel moto relativo di due corpi di masse variabili. Ref. 4206.

76: D. Caponiti, L'andamento dell'attività solare dedotto dalle osservazioni eseguite a Palermo e a Catania dal 1877 al 1952. Ref. 6308.

77: C. Strano, G. Leonardi, L'attività del Sole nell'anno 1952. Ref. 6370, 6651.

\section{Clneinnati}

174. Minor Planet Circulars Nr. 851 - 1002. Ref. 7536.

\section{Coimbra}

175. Publicações do Observatório Astronómico da Universidade de Coimbra.

Nr. 1: M. dos Reis, Sobre a teoria da refracção astronómica. Ref. 3109.

176. Efemérides Astronómicas para o ano de 1954. Ref. 403.

\section{Córdoba}

177. Observatorio de Córdoba. Tirada Aparte.

Nr. 58: J. Sahade, Radial velocities of five southern proper-motion stars. Ref. 9223.

59: E. Gaviola, Eta Carinae. ПI. The spectrum. Ref. 11318.

60 : J. Bobone, Observations of comets, Phoebe and Jupiter VI. Ref. 7633, 7701, §81.

61: J. Sahade, A note on V 449 Scorpii. Ref. 11127.

\section{Delaware}

178. Contributions from the Perkins Observatory.

Nr. 34: P. C. Keenan, G. Keller, Spectral classification of the highvelocity stars. Ref. 9530. 
35: G. Keller, M. Fenwick, Tabulation of the incomplete FermiDirac functions. Ref. 224.

36: G. Keller, The effect of electron screening on thermonuclear energy generation. Ref. 5211.

179. Contributions from the Perkins Observatory.

(2) Nr. 1: G. Keller, Astronomical «seeing" and its relation to atmospheric turbulence. Ref. 7243.

Dorpat. Siehe Tartu.

Dublin

180. Contributions from the Dunsink Observatory.

Nr. 6: A. N. Argue, Photoelectric stellar photometry using an E.M.I. photomultiplier. Ref. 9402.

7: H. A. Brück, D. A. Jackson, An attempt to measure interferometrically the widths of chromospheric lines at the total solar eclipse of 25 February 1952. Ref. 6210.

\section{Edinburgh}

181. Communications from the Royal Observatory, Edinburgh.

Nr. 6: M. A. Ellison, The $\mathrm{H} \alpha$ radiation from solar flares in relation to sudden enhancements of atmospherics on frequencies near $27 \mathrm{Kc} / \mathrm{s}$. Ref. 6809.

7: R. Wilson, The ionized helium series originating from the fifth quantum level. Ref. 246.

Evanston, $\mathrm{Ill}$.

182. Contributions from the Dearborn Observatory.

Nr. 4: K. A. Strand, The orbital motion of 70 Ophiuchi. Vgl. AJB 52 Ref. 10119.

K. A. Strand, R. Spong, The parallax and mass-ratio of 70 Ophiuchi. Vgl. AJB 52 Ref. 9306.

\section{Fort Davis}

183. Contributions from the McDonald Observatory, University of Texas.

Nr. 215: W. P. Bidelman, The spectra of certain stars whose atmospheres may be deficient in hydrogen. Ref. 9504.

216: H. L. Johnson, W. W. Morgan, Fundamental stellar photometry for standards of spectral type on the revised system of the Yerkes Spectral Atlas. Ref. 9407.

217: H. L. Johnson, Magnitudes, colors, and spectral types in M 39. Ref. 12110.

218: H. L. Johnson, Magnitudes and colors in NGC 752. Ref. 12111.

219: H. L. Johnson, Photoelectric observations of visual double stars. Ref. 10113.

220: G. R. Burbidge, E. M. Burbidge, The outer atmospheres of some Be stars. Ref. 5105.

221: N. G. Roman, The spectrum of BD $+67^{\circ} 922$. Ref. 9555.

222: D. L. Harris, Note on the HR diagram of the pleiades. Ref. 12106.

223: E. M. Burbidge, G. R. Burbidge, Interstellar lines in the spectra of eight early-type stars. Ref. 12505 .

224: W. W. Morgan, D. L. Harris, H. L. Johnson, Some characteristics of color systems. Ref. 9412. 
225: S. S. Provin, Variation in light of the spectrum variable 56 Arietis. Ref. 111100.

226: W. A. Hiltner, Spectrographic observations of SV Camelopardalis. Ref. 11107.

227: G. R. Burbidge, E. M. Burbidge, The Balmer decrement in some Be stars. Ref. 9510.

228: D. L. Harris, Note on the Cepheid variable Zeta Geminorum. Ref. 11148.

229: E. M. Burbidge, G. R. Burbidge, EM Cyg, a possible exnova. Ref. 11302.

Freiburg i. Br.

184. Veröffentlichungen des Fraunhofer-Instituts Freiburg i. Br.

Sonnen-Zirkular für die Monate Oktober 1952-September 1953. $\S 63,65,66,67,68,72,127$.

185. Mitteilungen aus dem Fraunhofer-Institut, Freiburg i. Br.

Nr. 10: K. O. Kiepenheuer, Ist das allgemeine Magnetfeld der Sonne meßbar? Ref. 6123.

11: U. Becker, Ủber eine Beziehung zwischen erdmagnetischer Unruhe und der Anordnung der Sonnenflecken. Ref. 6805.

12: U. Becker, K. O. Kiepenheuer, Ưber ein solares Maß der Fleckentätigkeit. Ref. 3304 .

13: Vgl. AJB 54.

14: U. Becker. ther eine Beziehung zwischen den Filamenten und der Helligkeitsverteilung der Korona in der Eisenlinie $\lambda 5303$. Ref. 6605 .

15: K. O. Kiepenheuer, Was ist ein Aktivitätszentrum auf der Sonne? Ref. 6324.

16: K. O. Kiepenheuer, Über die Beziehung zwischen Protuberanzen und Korona. Ref. 6624.

17: K. O. Kiepenheuer, Photoelectric measurements of solar magnetic fields. Ref. 6122 .

Gent

186. Publications de l'Observatoire de Genève.

(A) 511 (45): G. Tiercy, Commentaires sur le service chronométrique de l'Observatoire de Genève après quelques modifications récentes. Ref. 2326.

12 (46): G. Tiercy, Sur une formule de calcul de points servant à classer les chronomètres observés. Ref. 2327.

13 (47): M. Golay, Etude d'un photomètre photoélectrique monté sur le téléscope Schær de $100 \mathrm{~cm}$. Ref. 2217.

14 (48): P. B. Bouvier, Les équations intégrales de Milne pour une atmosphère parfaitement diffusante. Ref. 5104 .

\section{Genova}

187. Istituto Idrografico della Marina.

Effemeridi Nautiche 1954, 1955. Ref. 422.

Gent

188. Universiteit te Gent. Sterrenkundig Instituut.

Nr. 15: D. de Smet-de Potter, M. Neyts, Over het bestaan van absorberende nevels in Cassiopeia. Ref. 12816.

16: D.de Smet-de Potter, M. Ney ts, Etude spectrophotométrique et statistique d'une région obscure dans Cassiopée. Ref. 12519. 


\section{Glasgow}

189. Glasgow University Observatory Reprint.

Nr. 33: A. E. Roy, Miss Blagg's formula. Ref. 7021.

34 35: Vgl. AJB 54.

36: D. G. Ewart, The constants of the velocity ellipsoid from the radial velocities of 820 stars. Ref. 12330.

\section{Golossejewo}

190. Mitteilungen (Iswestija) des Astronomischen Hauptobservatoriums der Akademie der Wissenschaften der Ukrainischen Sowjetrepublik.

1: W. P. Zessewitsch, Aufstellung eines großen photometrischen Standards in Aquarius. Ref. 9425.

S. G. Gordeladse, Die Massenejektion beim Ausbruch von Neuen Sternen. Ref. 11304.

A. S. Zessjulewitsch, Versuchsbeobachtungen am Vertikalkreis nach der Talcottschen Methode. Ref. 1211.

W. W. Konin, Untersuchung des Schraubenwertes eines Okularmikrometers. Ref. 2223.

\section{Göttingen}

191. Veröffentlichungen der Universitäts-Sternwarte zu Göttingen.

Nr. 104: P. ten Bruggencate, Die Temperatur von Protuberanzen. Vgl. AJB 52 Ref. 6609.

105: W. Priester, Photometrie von Fraunhofer-Linien mit der Lum. mer-Platte, angewandt auf die Mitte-Rand-Variation der Natrium D-Linien. Ref. 6425.

106: H. Haffner, Das neue Irisphotometer der Göttinger Sternwarte. Ref. 1212.

107: G. Elste, Die Entzerrung von Spektrallinien unter Verwendung von Voigt-Funktionen. Ref. 211.

\section{Granada}

192. Boletín Mensual del Observatorio de Cartuja, Granada. Observaciones astronómicas y sísmicas. Enero a Diciembre de 1952. Ref. 6370.

\section{Greenwich}

193. Greenwich Astronomical Results 1939, 1945. Ref. 2332, 6001, 7101, 7116, 7301, 7401, 7601, 7701, 7801, 7805, 10128, 13230 .

194. Greenwich Photo-heliographic Results 1941, 1942, 1943. Ref. 6370, 6651.

195. Greenwich Magnetic and Meteorological Observations 1940, 1941, 1945. Nicht referiert.

196. Report of the Astronomer Royal to the Board of Visitors of the Royal Greenwich Observatory. Ref. 1101.

197. The Nautical Almanac and Astronomical Ephemeris for the Year 1954. Ref. 404.

198. Apparent Places of Fundamental Stars 1954. Ref. 417.

199. The Abridged Nautical Almanac for the Year 1954. Ref. 426.

200. The Air Almanac 1954. Ref. 431.

201. The Star Almanac for Land Surveyors for the Year 1954. Ref. 433.

\section{Groningen}

202. Publications of the Kapteyn Astronomical Laboratory at Groningen.

Nr. 55: L. Plaut, An investigation on the eclipsing binaries brighter than photographic magnitude 8.50 at maximum. Ref. 11126. 


\section{Hamburg}

203. Mitteilungen der Hamburger Sternwarte in Bergedorf.

9 86: J. Stock, Die Schwärzungsabhängigkeit der isophoten Wellenlänge bei chromatischen Objektiven. Ref. 2251.

87: M. Beyer, Der Lichtwechsel und die Lage der Rotationsachse des Planeten 433 Eros während der Opposition 1951-52. Ref. 7531.

22 231: W. Becker, J. Stock, Dreifarbenphotometrie des Sternhaufens M 67 (NGC 2682). Ref. 12102.

232: P. Wellmann, Der Bedeckungsveränderliche EE Pegasi. Ref. 11139.

233: G. Thiessen, Zur Feinstruktur des Farbenhelligkeitsdiagramms des Sternhaufens Coma Berenices. Ref. 12124.

234: G. Thiessen, Der Effekt der interstellaren Polarisation in der Sonnenkorona. Ref. 6729.

235: J. Ax, Ein spektralphotometrischer Vergleich zwischen Schnellläufern und normalbewegten Sternen. Ref. 9503 .

236: D. Labs, J. Stock, Ein lichtelektrisches Sternphotometer mit Wechselstromverstärkung. Die Lichtkurve des Bedeckungsveränderlichen AK Herculis. Ref. 2225.

237: P. Wellmann, Die spektrographische Einrichtung des Bergedorfer $1 \mathrm{~m}$-Spiegelteleskops. Ref. 1215.

238: D. Labs, H- und K-Emissionen im Spektrum von $\xi$ Boo A und 70 Oph A. Ref. 9534.

204. Jahresbericht der Hamburger Sternwarte in Bergedorf für das Jahr 1952. Ref. 1101.

205. Zweiter Katalog der Astronomischen Gesellschaft. Band 6, 7, 8, 9. Ref. 9124.

206. Bergedorfer Spektraldurchmusterung. Band 5. Ref. 9575.

207. Deutsches Hydrographisches Institut. Jahresbericht Nr. 7, 1952. Ref. 1101.

208. Nautisches Jahrbuch oder Ephemeriden und Tafeln für das Jahr 1954. Ref. 423.

\section{Heidelberg}

Astronomisches Rechen-Institut

209. Astronomisch-Geodätisches Jahrbuch für 1954. Ref. 405.

210. Astronomischer Jahresbericht. 50. Band. Die Literatur des Jahres 1950. Ref. 701.

211. Veröffentlichungen des Astronomischen Reohen-Instituts zu Heidelberg.

Nr. 5: F. Gondolatsch, Erdrotation, Mondbewegung und das Zeitproblem der Astronomie. Ref. 13109.

212. A. Kopff, Supplement-Katalog des FK3 (FK3 Supp.). Ref. 9111.

213. Astronomische Grundlagen für den Kalender 1955. Ref. 418.

214. Nachrichtenblatt der Astronomischen Zentralstelle. 7. Jahrgang Nr. 1-10. Vorläufige Mitteilung Nr. 172-205.

Landessternwarte

215. Veröffentlichungen der Staatlichen Sternwarte Heidelberg-Königstuhl.

16: K. Reinmuth, Katalog von 6500 genauen photographischen Positionen Kleiner Planeten. Ref. 7515.

216. Mitteilungen der Badischen Landessternwarte Heidelberg-Königstuhl.

Nr. 91: G. R. Miczaika, Radialgeschwindigkeitsmessungen von $\zeta$ Tauri 1949-1951. Ref. 9220 . 
92: A. König, Eigenbewegungen von 66 Sternen in der Umgebung von $\alpha$ Persei. Ref. 9210.

93: K. Bahner, G. R. Miczaika, Ein Gerät zur Entzerrung von Eichkurven lichtelektrischer Plattenphotometer. Ref. 2204.

94: G. R. Miczaika, Utber das System U Cephei. Ref. 11124.

95: G. R. Miczaika, Light-variability of the Of-type spectroscopic binary $\mathrm{BD}+40^{\circ} 4220$. Ref. 10203 .

\section{Helsinki}

217. Sonderdrucke des Astronomischen Observatoriums Helsinki.

P. Kustaanheimo, Comparison between the photometries of the solar corona of the total eclipse of July 9,1945 , as performed at the observatories of Stockholm and Helsinki. Ref. 6205.

P. Kustaanheimo, On some special functions in Galois fields. Ref. 4138.

G. Järnefelt, An attempt to work out a finite system corresponding to a special case of Schrödinger's non-relativistic model of the linear harmonic oscillator. Ref. 4133.

G. Järnefelt, Ein endliches Weltbild. Ref. 4134.

P. Kustaanheimo, A note on the transformability of spherically symmetric metrics. Ref. 4139.

G. Järnefelt, Karl Fridhiof Sundman. Minnestal vid Finska Vetenskaps-Societetens sammanträde den 21 maj 1951. Ref.1013.

\section{Istanbul}

218. Publications of the Istanbul University Observatory.

Nr. 47: E. Balli, Observations des taches solaires en 1952. Ref. 6370.

\section{Johannesburg}

219. Union Observatory. Circular.

63 (113): J. A. Bruwer, E. L. Johnson, Occultations of stars by the moon, 1951. Ref. 7360 .

J.A. Bruwer, Photographic observations of minor planets. Ref. 7536.

J. A. Bruwer, Approximate positions of minor planets. Ref. 7536.

J. A. Bruwer, Photographic observations of comets. § 81.

E. L. Johnson, Photographic observations of special minor planets. Ref. 7536.

E. L. Johnson, Approximate positions of minor planets. Ref. 7536.

E. L. Johnson, Photographic observations of minor planets. Ref. 7536.

E. L. Johnson, Photographic observations of comets. § 81.

W. S. Finsen, Interferometer measures of double stars, Ref. 10128.

W. H. van den Bos, A study of Finsen's interferometer measures of double stars. 10102.

W. H. van den Bos, Micrometer measures of double stars. Ref. 10128.

W. H. van den Bos, Orbits of double stars. Ref. 10103, 10131.

W. S. Finsen, W. H. van den Bos, Micrometer measures of Juno. Ref. 7536.

219b.Annual report 1950, 1951. Ref. 1101. 


\section{Kasan}

220. Bulletin des Astronomischen Engelhardt-Observatoriums der Lenin-Staatsuniversität Kasan.

Nr. 29: B. N. Kadomskij, Anwendung der Methode des Längsspektrographen als photometrische Methode zur Bestimmung der Lichtkurve von RS Vulpeculae. Ref. 11111.

30 : A. A. Nefedjew, Ưber den Durchmesser der Venus. Ref. 7119. N. A. Tschudowitschewa, A. K. Iwanowa, Beobachtungen über die Veränderlichkeit der Breite des AstronomischenEngelhardt-Observatoriums auf Grund des neuen Programms im Jahre 1951. Ref. 13227.

221. Mitteilungen (Iswestija) des Astronomischen Engelhardt-Observatoriums der Lenin-Staatsuniversität Kasan.

Nr. 28: L. D. Agafonowa, A. I. Nefedjewa, Absolute Deklinationen von 536 Sternen des Fundamentalkatalogs Schwacher Sterne. Ref. 9101.

\section{Kiel}

222. Sonderdruck der Sternwarte Kiel.

E. Vitense, Die Wasserstoffkonvektionszone der Sonne. Ref. 6116.

M. Reichel, Zur Theorie der Spektroheliogramme. Ref. 6427.

Kiow

223. Publikationen (Publikazii) des Astronomisehen Observatoriums der Schewtschenko-Staatsuniversität Kiew.

Nr. 5: S. K. Wsechswjatskij, Neue Arbeiten über die Herkunft der Kometen und die Auswurftheorie. Ref. $\mathbf{5 5 3 3}$.

W. P. Konoplewa, Úber die Helligkeitsveränderung der kurzperiodischen Kometen Brorsen ${ }_{1}$ und Brooks ${ }_{2}$. Ref. 8109, 8110. W. I. Tscherednitschenko, Die säkulare Helligkeitsänderung des kurzperiodischen Kometen Faye. Ref. 8114.

P. N. Tschirwinskij, Utber die quantitativen Gesetzmäßigkeiten der chemischen Zusammensetzung der Himmelskörper. Ref. 5138.

N. A. Chinkulowa, Utber die Veränderung der Gesamtzahl der Koronaelektronen mit der Phase der Sonnentätigkeit. Ref. 6702.

S. K. Wsechswjatskij, E. E. Semanek, A. N. Sergejewa, Utber die Maß-Systeme der Sonnenaktivität. Ref. 6366.

N. A. Tschernega, Bestimmung der Breite des Astronomischen Observatoriums Kiew aus Beobachtungen in den Jahren 1949-1950. Ref. 1219.

W. P. Konoplewa, P. G. Duchnowskij, P. N. Polupan, E. W. Sandakowa, N. A. Chinkulowa, Beobachtungen von Kleinen Planeten am Astronomischen Observatorium Kiew. Ref. 7536.

Beobachtungen von Sternbedeckungen am Astronomischen $\mathrm{Ob}$ servatorium Kiew in den Jahren 1948-1950. Ref. 7360 .

Tätigkeitsbericht des Astronomischen Observatoriums der Schewtschenko-Staatsuniversität Kiew für 1950. Ref. 1101.

Tätigkeitsbericht des Astronomischen Observatoriums der Schewtschenko-Staatsuniversität Kiew für 1951. Ref. 1101.

(224). Zirkulare des Astronomischen Observatoriums der Schewtschenko-Staatsuniversität Kiew Nr. 61-65. Ref. 6370, 6651. 


\section{Kobenhavn}

225. Publikationer og mindre Meddelelser fra Københavns Observatorium.

Nr. 161: E. Sinding, The future orbit of comet 1898 VII (CoddingtonPauly). Ref. 8134.

162: M. Rudkjøbing, On the chemical composition and the energy production of Y Cyg. Ref. 5228.

M. Rudkjøbing, Revised calculation of the energy production of Y Cygni. Ref. 5229.

226. Union Astronomique Internationale. Circulaire Nr. 1387-1434.

227. Aktuelle Meddelelser fra Astronomisk Selskab Nr. 355-362.

\section{Kodaikanal}

228. Kodaikanal Observatory Bulletin.

Nr. 135: A. K. Das, Summary of prominence observations for the first half of 1951. Ref. 6651.

186: Nicht eingegangen.

137: Nicht eingegangen.

138: A.K. Das, Summary of prominence observations for the first half of 1952. Ref. 6651 .

229. Kodaikanal Observatory. Sonderdrucke.

A. K. Das, Can matter be created out of cosmic radiation ? Ref. 12706.

A. K. Das, K. Sethumadhavan, Eruptive prominence of February 26,1953 , and associated radio noise-burst. Ref. 6611 .

A. K. Das, A. S. Ramanathan, Distribution of radiation flux across a sunspot. Ref. 6309 .

R. Ananthakrishnan, Spectrophotometric study of sunspots. Ref. 6302.

A. K. Das, K. D. Abhyankar, Difference of temperature between pole and equator of the sun. Ref. 6407 .

A. K. Das, B. N. Bhargava, Radio noise-bursts from solar M-regions. Ref. 6520.

230. Annual Report of the Kodaikanal Observatory for the year 1952. Ref. 1101.

\section{Kraków (Krakau)}

231. Rocznik Astronomiczny Obserwatorjum Krakowskiego 1953. Supplemento Internationale Nr. 24. Ref. 421, 7358, 11010.

\section{Krim}

232. Mitteilungen (Iswestija) des Astrophysikalischen Observatoriums auf der Krim.

10: G. A. Schajn, W.A.Albizkij (Nekrolog). Ref. 1001.

A. B. Sewerny, W. L. Chochlowa, Untersuchung der Bewegungen und des Leuchtens der Sonnenprotuberanzen. Ref. 6643.

K. K. Tschuwajew, Elektrophotometrische Untersuchungen des Nachthimmelleuchtens in einigen Spektralbereichen. Ref. 72123 .

S. B. Pikelner, Interstellares Gas und Magnetfelder. Ref. 6319. S. B. Pikelner, G. A. Schajn, Der Charakter der Turbulenz im interstellaren Medium. Ref. 5320.

E. S. Brodskaja, Spektren und Helligkeiten von 400 O- bis B5-Sternen im Milchstraßenfeld mit dem Zentrum bei $\alpha=$ $23^{\text {h }} 27^{\text {m }}, \delta=+61^{\circ}$. Ref. 9508 . 
I. M. Kopylow, Spektren und Helligkeiten von 731 schwachen O- bis B5-Sternen im Milchstraßenfeld mit dem Zentrum bei $\alpha=1^{\text {b }} 25^{\text {m }}, \delta=+61^{\circ} 50^{\prime}$ (1950). Ref. 9533.

E. R. Mustel, Das Problem des Materieabflusses aus stationären Sternen. Ref. 6504.

G. A. Schajn, W. F. Hase, Ưber die Beziehung zwischen diffusen Gasnebeln und heißen Sternen. Ref. 12235.

I. S. Schklowskij, Versuch eines Helligkeitsvergleichs der Milchstraße im infraroten und im photographischen Licht. Ref. 12314.

S. B. Pikelner, Die Tonisation des Heliums in den Nebeln und die Temperaturen der O-Sterne. Ref. 5321.

I. M. Kopylow, Die Massen der Hüllen der Nouen Sterne. Ref. 11306.

W. F. Hase, G. A. Schajn, Ein neuer Nebel beim novaähnlichen Veränderlichen FU Orionis. Ref. 12215.

W. F. Hase, G. A. Schajn, Über einen neuen Nebel bei $\sigma$ Scorpii. Ref. 12216.

G. A. Schajn, W. F. Hase, Zweite Liste peripherer, diffuser Nebel. Ref. 12236.

W. F. Hase, Über die Struktur des Nebels IC 405 im Licht von $\mathbf{H} \alpha$ und im integralen Licht. Ref. 12217.

P. F. Schajn, Beobachtungen Kleiner Planeten in Simeĩs im Jahre 1952. Ref. 7536.

\section{Kyoto}

233. Contributions from the Institute of Astrophysics, Kyoto University.

Nr. 28: S. Miyamoto, Residual intensity and contour of the solar K-line. Ref. 6419.

29: A. Hattori, I. Kawaguchi, S. Miyamoto, T. Saigusa, Note on the optical thickness and the temperature of the planetary nebulae. Ref. 5308.

30: S. Miyamoto, A relationship between the emission line contours and the stability of the atmospheres of the P Cygni stars. Ref. 5124.

31: T. Kogure, On the radiation field of the Wolf-Rayet star. Ref. 5120.

32: M. Kanno, On the radiation field of Be-atmospheres with spherical symmetry. Ref. 5118.

33: S. Miyamoto, On the interpretation of shell spectra. Ref. \$125.

34: T. Araki, Utber das Erschaffen der Materie und das sich ausdehnende Universum. Ref. 4103.

35: S. Miyamoto, The atmospheres of the P Cygni stars. Ref. 5126.

36: S. Miyamoto, Theoretical contour of the solar Lyman Alpha radiation. Ref. 6110.

\section{Le Houga}

234. Publications de l'Observatoire du Houga.

Nr. 16: M. Petit, Etoiles à sursauts lumineux. Catalogue, propriétés, bibliographie. Ref. 11213.

\section{Leiden}

235. Annalen van de Sterrewacht te Leiden.

20 12: C. J.van Houten, Discussion of ninety variable stars in the southern hemisphere. Ref. 11202. 
Lembang, Java

236. University of Indonesia, Bosscha Observatory, Lembang, Java. Report for the years 1951-1952. Ref. 1101 .

\section{Leningrad}

237. Publikationen (Trudy) des Astronomischen Observatoriums Leningrad.

16: A. A. Nikitin, Über die Anregung der Sauerstoffatome in der Sonnenatmosphäre. Ref. 6111.

S. D. Gutschabasch, Die Streuung des Lichts in einem Medium mit veränderlicher Streucharakteristik. Ref. 214.

T. A. Agekjan, Die Dynamik des Durchgangs von Sternen durch Wasserstoffwolken. Ref. 5301.

T. A. Agekjan, ther die Ursachen des Anwachsens der Restgeschwindigkeiten der Sterne. Ref. 12323.

I. N. Minin, Anwendung der Gleichungen der stellaren Hydrodynamik auf die kugelförmigen Sternhaufen. Ref. 12134.

R. B. Schazowa, Die Asymmetrie der Radialgeschwindigkeiten der Sterne. Ref. 12337.

R. B. Schazowa, Ưber die Stabilität des lokalen Systems. Ref. 12338.

O. A. Melnikow, Spektralphotometrie von $\alpha$ Cygni. Ref. 9540.

N. W. Nowotschadowa, Die Konturen der Wasserstofflinien bei den Sternen früher Spektralklassen. Ref. 9549.

N. N. Sytinskaja, W. W. Scharonow, Untersuchung des Reflexionsvermögens der Mondoberfläche. Ref. 7375.

M. W. Bannowa, Versuch der Ableitung von Isophoten auf der Saturnscheibe. Ref. 7704.

S. W. Makarow, M. A. Swetschnikow, Die Kontur des Erdschattens bei der Mondfinsternis vom 26. September 1950. Ref. 7348.

N. S. Orlowa, Streuungsdiagramme einiger Substanzen. Ref. 232.

S. W. Gromow, Über eine Methode der Regularisierung der Erde. Ref. 13110.

S. W. Gromow, Inversion und Neigung der Lotlinien. Ref. 13111.

238. Bulletin des Instituts für Theoretische Astronomie der Akademie der Wissenschaften der UdSSR.

55 (68): G. A. Tschebotarjow, Analytische Theorie der Bewegung von Hilda. Ref. 7519.

N. B. Jelenewskaja, Entwicklung der Störungsfunktion in eine Fourier-Reihe bezüglich der Neigung. Teil 2. Entwicklung der Störungsfunktion im räumlichen, kreisförmigen, eingeschränkten Dreikörperproblem in eine Fourier-Reihe bezüglich der Neigung. Ref. 4217.

S. G. Scharaf, Entwicklung einiger Funktionen der Koordinaten der elliptischen Bewegung in Reihen bis zur 9. Potenz der Exzentrizität. Ref. 4238.

W. F. Proskurin, T. I. Maschinskaja, Die Darstellung der Ceres-Beobachtungen unter Berücksichtigung der Störungen erster Ordnung. Ref. 7514.

F. B. Chanina, Neue Elemente des Kleinen Planeten 171 Ophelia. Ref. 7536.

6 (69): G. A. Merman, Über die hinreichenden Bedingungen für den Einfang im eingeschränkten, hyperbolischen Dreikörperproblem bei engen, doppelten Annäherungen. Ref. 4223. 
G. A. Merman, Beispiel eines Einfangs im ebenen, eingeschränkten, hyperbolischen Dreikörperproblem. Ref. 4224.

7 (70): G. A. Tschebotarjow, Die Entwicklung der Bahnen des äußeren Randes des Asteroidenrings. Ref. 7520.

I. W. Galibina, Bestimmung der ursprünglichen Bahn des Kometen 1925 VII. Ref. 8138.

M. J. Schmakowa, Untersuchung der Bahnform des Kometen 1925 VII. Ref. 8138.

W. F. Proskurin, Über den Einfang im Beispiel von O.J. Schmidt. Ref. 4233.

G. E. Chrapowizkaja, Über einen Fall des Einfangs im Dreikörperproblem. Ref. 4208.

N. G. Kotschina, Beispiele der hyperbolischen und hyperbolisch-elliptischen Bewegung im eingeschränkten, hyperbolischen Dreikörperproblem. Ref. 4218.

F. B. Chanina, Die Bahnelemente des Kleinen Planeten 1572 (1949 SC). Ref. 7536.

8 (71): Ergebnisse der Konferenz über das "Astronomische Jahrbuch der UdSSR;. Ref. 408.

M. F. Subbotin, Das "Astronomische Jahrbuch der UdSSR" und die Hauptaufgaben der Ephemeridenastronomie. Ref. 410. A. M. Gishizkij, Das "Astronomische Jahrbuch der UdSSR" (Kurzer historischer Abriß der Entstehung und Entwicklung des «Jahrbuchs》). Ref. 409.

I. D. Shongolowitsch, Zur Geschichte der Entstehung der nautischen und aeronautischen astronomischen Ephemeriden in unserem Land. Ref. 465.

D. K. Kulikow, Die Mechanisierung der astronomischen Rechnungen. Ref. 315.

D. W. Sagrebin, Über die Berechnung der Mondephemeriden mit Lochkartenmaschinen. Ref. 7326.

239. Astronomisches Jahrbuch der UdSSR für das Jahr 1956. Ref. 407.

240. Ephemeriden Kleiner Planeten für das Jahr 1954. Ref. 7501.

\section{Liège}

241. Institut d'Astrophysique. Collection in $4^{\circ}$ de Spectroscopie et Astrophysique.

Nr. 40: A. Monfils, J. Duchesne, Fonction potentielle de vibration de la molécule $\mathrm{C}_{2} \mathrm{~F}_{4}$. Nicht referiert.

41: A. Monfils, Le spectre infrarouge et la structure de la molécule $\mathrm{SiH}_{3} \mathrm{Cl}$. Nicht referiert.

42: D. Jehoulet, RU Cam, céphéide probable de type II. Ref. 11150.

43: B. Rosen, P. Swings, Carbon stars, comets and combustion phenomena. Ref. 9556.

44: P. Ledoux, Sur l'existence d'un noyau convectif au centre des étoiles. Ref. 5215.

45: F. Lenouvel, D. Jehoulet, La courbe de lumière de RU Cam. Ref. 11153.

46: P. Swings, Le rôle des poussières dans les atmosphères des étoiles froides. Ref. 9566.

47: J. Duchesne, Quelques réflexions sur l'évolution récente du problème de la structure moléculaire. Nicht referiert.

48: J. Duchesne, L. Burnelle, Ground and excited electronic states and molecular vibrations of some polyatomic molecules. Nicht referiert. 
49: W. Benesch, M. Migeotte, L. Neren, Investigations of atmospheric CO at the Jungfraujoch. Ref. 7233.

50: P. Swings, Nouvelles correspondances entre les spectres des comètes et des étoiles $\mathrm{N}$. Ref. $\mathbf{8 0 3 1}$.

242. Institut d'Astrophysique. Collection de Mémoires in $8^{\circ}$.

Nr. 349: P. Swings, Astrophysies and industry. Ref. 628.

350: Vgl. AJB 52 Ref. 5213.

351: Vgl. AJB 52 Ref. 7245.

352: La Physique des Comètes. Communications présentées au quatrième Colloque International d'Astrophysique, tenu à Liège les 19, 20 et 21 septembre 1952. Ref. 1199.

353: J. Swensson, Remarques sur l'identification dans les spectres d'objets célestes, de raies interdites dues à Cr III, Mn III, Co III et Ni III. Ref. 9565.

354: P. Swings, Note sur le quatrième colloque international d'astrophysique tenu à Liège les 19 et 20 septembre 1952. Ref. 1192.

355: J. Duchesne, Comparaison des résultats par spectroscopie infrarouge et centimétrique. Nicht referiert.

356: P. Ledoux, Les étoiles variables intrinsèques. Ref. 11005.

357-360: Vgl. AJB 54.

361: E. Vigroux, M. Migeotte, L. Neven, Etude, à grande dispersion, des bandes d'absorption de l'ozone à $9 \mu, 4.75 \mu, 3.59 \mu$ et $3.27 \mu$. Ref. 7259 .

362: E. Vigroux, M. Migeotte, L. Neven, Largeurs équivalentes des bandes d'ozone à $9.6 \mu, 4.75 \mu$ et $3.27 \mu$. Ref. 7260 .

363: Vgl. AJB 54.

364: P. Swings, A. McKellar, K. Narahari Rao, Spectra of the late N-type stars in the ultra-violet, violet and blue-green regions. Ref. 9567.

\section{London}

243. Communications from the University of London Observatory.

Nr. 9: Erscheint später.

10: Erscheint später.

11: C. W. Allen, World-wide diurnal variations in the $\mathrm{F} 2$ region. Ref. 7273.

12: K. R.W. Brewer, HD 50169, a spectrum variable with emission at $\mathrm{H} \alpha$. Ref. 9507.

\section{Los Angeles}

244. University of California. Astronomical Papers.

1 14: L. Larmore, A study of the motions of solar prominences. Ref. 6627.

2 1: Vgl. AJB 52 Ref. 4219.1

2: S. Herrick, Icarus and the variation of parameters. Ref. $\mathbf{7 5 0 6 .}$

\section{Lund}

245. Annals of the Observatory of Lund.

Nr. 12: N. Wieth-Knudsen, Studies on orbit determination of visual binary stars in some extreme cases. Ref. 10123, 10124, 10125.

246. Meddelande från Lunds Astronomiska Observatorium.

(1) Nr. 181: Vgl. AJB 54.

182: Vgl. AJB 54.

183: B.-A. Lindblad, The peculiar orbit of the Delta Aquarid meteors. Ref. 8254. 
247. Meddelande från Lunds Astronomiska Observatorium.

(2) Nr. 130: F. Nettelblad, Studies of astronomical scintillation. Results from photoelectric observations. Ref. 72163 .

Lyon

248. Publications de l'Observatoire de Lyon.

3 20: P. Proisy, Spectre de $\mathrm{NH}_{3}$ sous une faible pression. Ref. 236.

21: P. Proisy, Le spectre de $\mathrm{NH}_{3}$ et le spectre des comètes. Ref. 8025.

249. Publications de l'Observatoire de Lyon. Série I. - Astronomie.

(1) 5 23: R. Grandmontagne, Remarques sur le calcul des températures de l'atmosphère. Ref. 7240.

\section{Madrid}

250. Boletín Astronómico del Observatorio de Madrid.

4 6: R. Carrasco, Identificación del asteroide $1950 \mathrm{TD}_{3}$ con el 497 Iva. Ref. 7536.

E. Gullón, Protuberancias solares. Ref. 665I.

E. Gullón, Observaciones de manchas solares. I. Números relativos de Wolf. Ref. 6370.

E. Gullón, Observaciones de manchas solares. II. Estadística de manchas y superficie de las mismas. Ref. 6370.

R. Carrasco, Observaciones fotográficas del cometa Peltier (1952-d). Ref. 8158.

R. Carrasco, J. M. Torroja, Observaciones fotográficas de pequeños planetas (posiciones exactas). Ref. 7536.

251. Universidad de Madrid. - Facultad de Ciencias. Seminario de Astronomia y Geodesia. Publicación.

Nr. 17: R. Carrasco, M. Pascual, Rectificación de la orbita del asteroide 1528 Conrada. Ref. 7536.

18: J. M. González-Aboín, Orbita de ADS $1709=\Sigma 228$. Ref. 10131.

19: J. Baltá Elías, Recientes progresos en radioastronomía. Radiación solar hiperfrecuente. Ref. 12615.

20: J. M. Torroja, A. Vélez, Corrección de la órbita del asteroide $1452\left(1938 \mathrm{DZ}_{1}\right)$. Ref. 7536.

21: J. M. Torroja, Calculo con cracovianos. Ref. 118.

22: S. Arend, Los polinomios ortogonales y su aplicación en la representación matemática de fenómenos experimentales. Ref. 102.

\section{Manchester}

252. Astronomical Contributions from the University of Manchester. Series II. Jodrell Bank Reprint.

(2) Nr. 56: R. Hanbury Brown, C. Hazard, A model of the radiofrequency radiation from the galaxy. Ref. 12610 .

57-61 : Vgl. AJB 52.

62: Vgl. AJB 51.

63: Vgl. AJB 52.

64: Vgl. AJB 51 .

65-69: Vgl. AJB 52.

70: R. Hanbury Brown, C. Hazard, A radio survey of the Milky Way in Cygnus, Cassiopeia and Perseus. Ref. 12606. 
71-74: Vgl. AJB 52.

75: T. R. Kaiser, J. S. Greenhow, On the decay of radio echoes from meteor trails. Ref. 8216.

76: Vgl. AJB 52.

77: R. L. Closs, J. A. Clegg, T. R. Kaiser, An experimental study of radio reflections from meteor trails. Ref. 8208.

78: Vgl. AJB 52.

79: Report on Jodrell Bank to the Royal Astronomical Society council for 1952. Ref. 1101.

80: R. Hanbury Brown, C. Hazard, A survey of 23 localized radio sources in the northern hemisphere. Ref. 12607.

81: A. C. B. Lovell, Radio astronomy at Jodrell Bank. Ref. 12626.

82: T. R. Kaiser, Radio echo studies of meteor ionization. Ref. 8215.

83- 84: Vgl. AJB 54.

85: M.Almond, J. G. Davies, A. C. B. Lovell, The velocity distribution of sporadic meteors. IV. Extension to magnitude +8 , and final conclusions. Ref. 8201 .

86: I. C. Browne, T. R. Kaiser, The radio echo from the head of meteor trails. Ref. 8203.

87-89: Vgl. AJB 54.

90: R. Hanbury Brown, C. Hazard, Radio-frequency radiation from the spiral nebula Messier 81. Ref. 12608.

91: R. Hanbury Brown, C. Hazard, An extended radio-frequency source of extra-galactic origin. Ref. 12609.

92: R. Hanbury Brown, A symposium on radio-astronomy at Jodrell Bank. Ref. 1154.

93: R. C. Jennison, M. K. Das Gupta, Fine structure of the extraterrestrial radio source Cygnus I. Ref. 12620.

253. Astronomical Contributions from the University of Manchester. Series III.

(3) Nr. 8: D. C. Pack, The motion of a gas cloud expanding into a vacuum. Ref. 5817.

9-12: Vgl. AJB 54.

13: G. B. Whitham, The propagation of weak spherical shocks in stars. Ref. 5240.

14-18: Vgl. AJB 54.

19: Z. Kopal, Some remarks on the interpretation of apsidal-motion constants in close binary systems. Ref. 10004.

\section{Milano-Merate}

254. Contributi dell'Osservatorio Astronomico di Milano-Merate. Nuova Serie.

Nr. 40: A. Masani, Contributo allo studio delle atmosfere stellari. I. Il gradiente adiabatico. Ref. 5122 .

41: F. Zagar, Sul calcolo del gradiente adiabatico. Ref. 5141.

42: F. Zagar, Luigi Volta. Ref. 1001.

43: S. Leone, Misure fotografiche di binarie visuali. Ref. 10128.

44: S. Leone, Rifrazione differenziale. Ref. 3106.

45: A. Masani, Sull'importanza della pressione di radiazione agli effetti della instabilità per moti convettivi nell'interno delle stelle. Ref. 5218.

\section{Mizusawa}

255. Publications of the International Latitude Observatory of Mizusawa.

1 2: T. Hattori, Latitude observations with floating zenith telescope at Mizusawa. Part II. Ref. 13211. 


\section{Moskau}

256. Publikationen (Trudy) des Staatlichen Astronomischen Sternberg-Instituts.

22: G. F. Sitnik, Utber das potentiometrische Schaltschema zur Kontrolle des elektrischen Verhaltens einer Glühlampe als Lichtquelle. Ref. 241.

E. R. Mustel, Die bolometrischen Korrektionen und die Farbenindizes für Sterne früher Spektralklassen. Ref. 9716.

A. G. Massewitsch, Über den Aufbau und die Energiequellen der Riesen später Spektralklassen. Ref. 5219.

J. N. Lipskij, Berechnung der Masse der Mondatmosphäre auf Grund von Polarisationsuntersuchungen. Ref. 7317.

S. M. Rajtburd, Relative Spektralphotometrie von $\lambda$ Cephei und Bestimmung seiner Farbtemperaturen. Ref. 9603.

E. A. Makarowa, Utber den Einfluß des photographischen Schleiers auf die Messung relativer Intensitäten. Ref. 2246.

23: N. F. Florja, N. P. Kukarkina, Über 57 langperiodische Cepheiden. Ref. 11201.

W. P. Zessewitsch, B. A. Ustinow, Untersuchung des Blashko-Effekts. Ref. 11168.

P.N. Cholopow, Die scheinbare Verteilung der Sterne in zwanzig kugelförmigen Sternhaufen. Ref. 12131.

257. Mitteilungen (Soobschtschenija) des Staatlichen Astronomischen SternbergInstituts.

Nr. 88-89: A. A. Orlow, Fast kreisförmige periodische Bewegungen eines materiellen Punktes unter Einwirkung der Newtonschen Anziehung eines Sphäroids. Ref. 4230.

A. A. Orlow, Über die Integration der Differentialgleichungen der gestörten Bewegung in rechtwinkligen Koordinaten nach der Methode des kleinen Parameters. Ref. 4231.

G. F. Sultanow, Die theoretischen Verteilungen der Bahnelemente der Splitter des hypothetischen Olbersschen Planeten. Ref. 5529.

90-91: G. P. Pilnik, Ǔber die zu bestimmende Neigung eines Passageninstruments. Ref. 2510.

J. P. Gorelow, Ủber die Änderung der Neigung der horizontalen Achse des Passageninstruments Bamberg in Abhängigkeit von der Temperaturänderung. Ref. 2504.

92: B. M. Schtschigolew, P. T. Resnikowskij, Utber die Anwendung der Rungeschen Methode bei der numerischen Lösung der Gleichungen der Himmelsmechanik. Ref. 115.

J. L. Gasarjan, Ưber den Chazyschen Beweis der Unmöglichkeit des Einfangs im Dreikörperproblem. Ref. 4213.

J. L. Gasarjan, Verbesserung der Bahnelemente des Kleinen Planeten 1036 Ganymed. Ref. 7536.

93: I. S. Schtscherbina-Samojlowa, Untersuchung des Spektrographen des Kutschinoer Astrophysikalischen Observatoriums des Staatlichen Astronomischen Sternberg-Instituts. Ref. 1226.

94: W. W. Podobed, Bestimmung der Neigungs- und Azimutverbesserungen der Horizontalachse wegen der Zapfenungleichheit. Ref. 2512.

E. J. Bugoslawskaja, Photographische Beobachtungen Kleiner Planeten. Ref. 7536.

K. N. Jach on tow, Genauigkeitsvergleich der Messungen außergalaktischer Nebel und Sterne auf Aufnahmen mit dem $15^{\prime}$ Astrographen des Staatlichen Astronomischen Sternberg-Instituts Moskau. Ref. 12412. 
E. J. Bugoslawskaja, K. S. Mansurowa, Die Eigenbewegung des planetarischen Nebels NGC 6826 (GC 4514). Ref. 12205. J. P. Pskowskij, Erfahrung über die Verstärkung des Negativbildes mittels Zusatzbelichtung. Ref. 2250.

95: M. I. Uranowa, Utber die Eigenbewegungen von Sternen im Gebiet der Nova Lacertae 1910. Ref. 9214.

L. N. Radlowa, Infrarothelligkeiten roter Sterne. Ref. 9414.

L. N. Radlowa, Infrarote Sterne im Gebiet von P Cygni. Ref. 9415 .

D. K. Karimowa, Eigenbewegungen von 67 Sternen. Ref. 9209.

258. Akademie der Wissenschaften der UdSSR und Staatliches Astronomisches Sternberg-Institut.

B. W. Kukarkin, P. P. Parenago, J. I. Jefremow, P. N. Cholopow, Fünfter Nachtrag zur ersten Ausgabe des Generalkatalogs Veränderlicher Sterne. Ref. 11004.

\section{Mount Hamilton}

259. Contributions from the Lick Observatory.

(2) Nr. 45: J. Neyman, E. L. Scott, C. D. Shane, On the spatial distribution of galaxies: A specific model. Ref. 4407.

46: G. E. Kron, K. C. Gordon, The system of Alpha Coronae Borealis. Ref. 11116.

47: Vgl. AJB 54.

48: G. H. Herbig, B. A. Turner, The spectroscopic binary 12 Comae Berenices. Ref. 10201.

49: G. E. Kron, H. S. White, S. C. B. Gascoigne, Red and infrared magnitudes for 138 stars observed as photometric standards. Ref. 9409.

50: G. E. Kron, S. C. B. Gascoigne, Red and infrared magnitudes for 27 southern hemisphere stars of early spectral type. Ref. 9410 .

260. Lick Observatory Bulletin.

Nr. 526: S. Vasilevskis, The Lick proper-motion program and its relationship to some meridian-circle catalogues. Ref. 9216.

Mount Stromlo. Siehe Canberra.

Mount Wilson

261. Papers of the Mount Wilson Observatory.

8: R. E. Wilson, General Catalogue of Stellar Radial Velocities. Ref. 9224.

\section{München}

262. Veröffentlichungen der Sternwarte München.

4 11: H. Bucerius, Bahnbestimmung als Randwertproblem. IV. Ref. 4502.

12: F. Schmeidler, Über die Abhängigkeit der Bedingungen für visuelle astronomische Beobachtungen von der Wetterlage. Ref. 7253.

\section{Münster}

263. Mitteilungen der Universitäts-Sternwarte Münster.

Nr. 3: O. Günther, Photometrische Beobachtungen der Pallas in der Opposition 1951. Ref. 7533. 


\section{Napoli}

(264). Osservatorio Astronomico di Capodimonte-Napoli. Contributi Astronomici. Serie II.

3 17: A. Colacevich, Misure di polarizzazione della luce della corona eseguite in occasione dell'eclisse totale di sole del 25 febbraio 1952 a Chartum. Ref. 6210.

4 12: A. Colacevich, La variabile ad eclisse V 451 Ophiuchi. Ref. 11102.

(265). Osservatorio Astronomico di Capodimonte-Napoli. Collezione Miscellanea.

1 7: T. Nicolini, La figura della Terra. I. Ref. 13121.

8: T. Nicolini, Attilio Colacevich. Ref. 1001.

(266). Osservatorio Astronomico di Capodimonte-Napoli. Osservazioni.

1 3: M. Castellano, R. Barbatelli, Determinazioni di ascensione retta dei pianetini Vesta e Cerere e del pianeta Urano. Ref. 7505, 7801 .

(267). Osservatorio Astronomico di Capodimonte-Napoli. Contributi Geofisici Serie II.

Nr. 12: E. Guerrieri, Abbondanza e deficienza di pioggia dal 1949 al 1951. Temperature straordinarie nell'estate del 1952. Nicht referiert.

\section{Neuchâtel}

268. Rapport du directeur de l'Observatoire Cantonal de Neuchâtel. Ref. 1101.

\section{Now Haven}

269. Transactions of the Astronomical Observatory of Yale University.

24: I. Barney, Revised catalogue of the positions and proper motions of 10358 stars. Contained in the Astronomische Gesellschaft Zone between declinations $+25^{\circ}$ and $+30^{\circ}$, on the system of the FK3, and reduced without applying proper motions to the equinox 1950.0. Ref. 9102.

Odessa

270. Mitteilungen (Iswestija) des Astronomischen Observatoriums der Metschnikow-Staatsuniversität Odessa.

3: I. G. Shdanowa, W. P. Zessewitsch, Über die physikalische Natur der RV Tauri-Sterne. Ref. 111105.

W. W. Konin, Katalog der Deklinationen von 319 Sternen für das Äquinoktium 1950.0 aus Beobachtungen am Odessaer Meridiankreis in den Jahren 1947-1950. Ref. 9108.

L. F. Tscherniew, Katalog der Deklinationen von 125 polnahen Sternen für die Epoche und das Äquinoktium 1950.0. Ref. 9116.

E. N. Kramer, Kometenradianten und der Zusammenhang der Meteorströme mit den Kometen. Ref. 8016.

A. Schulberg, Utber die Bestimmung der Bahnelemente von Algol-Sternen mit ausgedehnten Atmosphären. Ref. 11130.

W.P. Zessewitsch, DL Herculis - ein Veränderlicher mit Blashko-Effekt. Ref. 11167.

S. W. Rublew, YZ Herculis. Ref. 111102.

E. P. Strelkowa, Untersuchung der Änderung des Farbenindex von RT Cygni. Ref. 111106.

G. T. Kowal, Der Bedeckungsveränderliche TT Lyrae. Ref. 11115 . 
W. P. Zessewitsch, DF Cygni. Ref. 11116.

G. T. Kowal, Untersuchung der Periode von DF Cygni. Ref. 11190.

A.Schulberg, Die Expedition des Astronomischen Observatoriums der Universität Odessa zur Beobachtung der Sonnenfinsternis vom 25. Februar 1952. Ref. 6210.

A. O. Kalenderjan, E. L. Schodo, Sonnenfleckenbeobachtungen am Astronomischen Observatorium Odessa. Ref. 6370. E. L. Schodo, Bemerkungen zu der Arbeit von E. L. Schodo "Die Rotation der Sonnenphotosphäre aus Fleckenbeobachtungen" in den Mitteilungen des Astronomischen Observatoriums der Staatsuniversität Odessa, Band II, Heft II. Ref. 6105.

\section{Ondřejov}

271. Publications of the Astrophysical Observatory of the Czechoslovak Akademy of Sciences Ondřejov.

Nr. 23: Z. Gregor, L. Krrivský, The variation of the frontal zone during the year in the area of the Atlantic and Europe and in relation to the solar activity. Ref. 6812 .

L. Kr̆ivský, The long-range variability of annual precipitation in Prague-Klementinum in the period 1805-1951 and in relation to the solar activity. Ref. 6819 .

24: J. Kleczek, Catalogue de l'activité des éruptions chromosphériques. II. Ref. 6651 .

25: F. Link, Z. Linková, Catalogue des éclipses de lune 1889 1938. I. Agrandissement de l'ombre terrestre. Ref. 7342.

J. Bou ška, F. Hřebík, Z. Švestka, Catalogue des cratères lunaires. Ref. 7365.

Oslo

272. The Institute of Theoretical Astrophysics Blindern-Oslo. Publication.

Nr. 1: A. Eliassen, E. Hoiland, E. Riis, Two-dimensional perturbation of a flow with constant shear of a stratified fluid. Nicht referiert.

2: J. Nordø, A statistical discussion of a possible connection between solar activity and sea-level pressure. Ref. 6826 .

273. The Institute of Theoretical Astrophysics, University of Oslo. Astrophysica Norvegica.

j 3: E. Palm, On the formation of surface waves in a fluid flowing over a corrugated bed and on the development of mountain waves. Nicht referiert.

274. The Institute of Theoretical Astrophysics Blindern, Norway. Reprint.

Nr. 3: G. Gjellestad, H.W. Babcock, The magnetically variable star HD 153882. Ref. 9803.

4: H. W. Dodson, E. R. Hedeman, L. Owren, Solar flares and associated $200 \mathrm{Mc} / \mathrm{sec}$ radiation. Ref. 6614 .

5: E. Tandberg-Hanssen, Influence d'un champ magnétique sur la stabilité des étoiles. Ref. 9811.

275. The Institute of Theoretical Astrophysics Blindern-Oslo. Report.

Nr. 2: Climatological data from Norway with regard to the solar eclipse, June 30, 1954. Ref. 6213.

3: G. Eriksen, Solar radio noise recording equipment built for the solar observatory at Harestua. Ref. 6522. 
276. Institutt for Teoretisk Astrofysikk Blindern-Oslo. Småtrykk.

Nr. 4: N. Herlofson, Stjerneskuddenes fysikk. Ref. 8211.

5: R. Guldal, Astronomiske begivenheter i 1952. Ref. 1369.

\section{Ottawa}

277. Contributions from the Dominion Observatory, Ottawa.

2 Nr. 12: D. W. R. McKinley, P. M. Millman, Long duration echoes from aurora, meteors, and ionospheric back-scatter. Ref. 72147.

13: J.L. Locke, L. Herzberg, The absorption due to carbon monoxide in the infrared solar spectrum. Ref. 6415 .

14: C. S. Beals, J. B. Oke, On the relation between distance and intensity for interstellar calcium and sodium lines. Ref. 12502.

15: P. M. Millman, D. W. R. McKinley, The Quadrantid meteor shower. Ref. 8262.

\section{Oxford}

278. Astrographic Catalogue 1900.0 Potsdam-Oxford Section. Dec. $+31^{\circ}$ to $+34^{\circ}$. Vol. 1. Ref. 9120.

279. Communications from the University Observatory, Oxford.

Nr. 37: I. W. Busbridge, Coherent and non-coherent scattering in the theory of line formation. Ref. 5106.

38: J. B. Sykes, The integral equation of limb-darkening. Ref. 5137.

39: G. Merton, Photographic places by a position-line method. Ref. 3107.

40: D. W. N. Stibbs, On a problem in the theory of formation of absorption lines. Ref. ó136.

41: T. D. Kinman, Motions in the sun at the photospheric level. III. The Evershed effect in sunspots of different sizes. Ref. 6327.

\section{Padova}

280. Osservatorio Astronomico di Padova. Pubblicazioni e Ristampe.

Nr. 97: C. Grubissich, Orbita definitiva della cometa 1911g (Beljawsky). Vgl. AJB 51 Ref. 8132.

98: G. Silva, Sulla determinazione pratica dei coefficienti di un polinomio di funzioni sferiche. Ref. 116.

99: A. Gennaro, Sulla maniera di tener conto dell'influenza dello schiacciamento del geoide sul moto dei teleproietti. Ref. 13410.

100: G. Pinto, Errori progressivi e periodici del misuratore di lastre "Gaertner". Vgl. AJB 52 Ref. 2508.

101: G. Silva, Come si misura il tempo. Ref. 2320.

102: G. Silva, Leggi e ipotesi dell'Astronomia. Ref. 627.

\section{Paris}

281. Contributions de l'Institut d'Astrophysique de Paris. Série A.

(A) Nr. 130: D. Barbier, Comparaison des spectres cométaires et de la haute atmosphère terrestre. Ref. 8003.

131: E. Schatzman, La structure et l'évolution des noyaux cométaires. Ref. 81628.

132-136: Vgl. AJB 52.

137: Notes sur l'absorption de l'ozone dans l'infra-rouge:

M. Migeotte, L. Neven, E. Vigroux, Structure fine de la bande à $9.6 \mu$. Vgl. AJB 52 Ref. 7245. 
E. Vigroux, M. Migeotte, L. Neven, Etude, à grande dispersion, des bandes d'absorption de l'ozone à $9 \mu, 4.75 \mu, 3.59 \mu$ et $3.27 \mu$. Ref. 7259 .

E. Vigroux, M. Migeotte, L. Neven, Largeurs équivalentes des bandes d'ozone à $9.6 \mu, 4.75 \mu$ et $3.27 \mu$. Ref. 7260 .

138: R. Michard, Les conditions physiques dans les grandes taches solaires déduites de leur spectre. Vgl. AJB 52 Ref. 6317, 53 Ref. 6344.

139: D. Barbier, Photométrie de la région ultraviolette de la lumière du ciel nocturne. Ref. 72100.

140: D. Barbier, La notion de température en astrophysique. Ref. 5001.

141: Vgl. AJB 54.

142: C. Pecker, La condition de continuité du flux. Ref. 5130.

143: R. Peyturaux, Sur l'assombrissement centre-bord du Soleil entre $6000 \AA$ et $23000 \AA$. Ref. 6423.

144: C. Pecker, Etude du diagramme gravité-flux. Ref. 5131.

145: H. van Regemorter, Détermination de la température de la surface du Soleil, par l'étude de l'intensité des raies du vanadium. Ref. 6426.

146: R. Rigollet, Photographie des météores en Haute Provence. Ref. 8228.

147: L. Divan, Loi de variation avec la longueur d'onde du coefficient d'absorption continue de la matière interstellaire. Ref. 12507.

148: J. Berger, L. Divan, A.-M. Fringant, Essai de détermination en valeur absolue du coefficient d'absorption continue de la matière interstellaire. Ref. 12503.

149: A.-M. Fringant, Sur la classification spectrale de RR Lyrae. Ref. 11144.

150: D. Chalonge, L. Divan, Classification stellaire à trois paramètres applicable aux étoiles des populations I et II. Ref. 9516.

151: D. Barbier, Quelques résultats sur le spectre de la lumière du ciel nocturne. Ref. 72101.

152: E. Vigroux, Contribution à l'étude expérimentale de l'absorption de l'ozone. Ref. 243.

153: P. Volmer, Vérification à l'aide d'un radar de l'altitude de disparition des traînées météoriques dont le radiant est connu. Ref. 8236.

154: B. Vau quois, P. Coupiac, M. Laffineur, Etude expérimentale des orages radioélectriques solaires. Ref. 6532.

282. Contributions de l'Institut d'Astrophysique de Paris. Série B.

(B) Nr. 93: R. Rigollet, Trois étoiles variables nouvelles dans les Gémeaux. Ref. 11216.

94: M. Mayot, G. Berthier, B. Pullman, Sur le calcul des charges électriques dans les hydrocarbures non alternants. Nicht referiert.

95: M. Mayot, G. Berthier, B. Pullman, Compléments sur le calcul du diamagnétisme des composés aromatiques. Nicht referiert.

96: R. Canavaggia, J.-C. Pecker, Les géantes jaunes. II. Spectres continus. Ref. 5107.

97: E. Schatzman, Sur l'existence d'un maximum à la fonction de luminosité. Ref. 9722.

98: R. Cayrel, Sur une cause d'erreur en spectrophotométrie. Ref. 9513.

99: R. Rigollet, Le bolide du 2 juillet 1949. Ref. 8265 . 
100: J.-C. Pecker, Tables d'ionisation nécessaires pour l'étude des étoiles $B$ dont l'atmosphère contient de l'hydrogène et de l'hélium. Ref. 5132.

101: E. Schatzman, Sur certaines réactions nucléaires d'importance astrophysique (IV). Ref. 5231.

102: E. Schatzman, Remarques sur la théorie cosmogonique de G. P. Kuiper. Ref. 5522.

103: R. Michard, Contribution à l'étude physique de la photosphère et des taches solaires. Ref. 6343 .

104: C. Pecker, Contribution à l'étude de la zone convective des étoiles. Ref. 5129.

105: R. Cayrel, Effets secondaires renforçant une cause d'erreur en spectrophotométrie. Ref. 9514.

Le Bureau des Longitudes.

283. Connaissance des Temps ou des mouvements célestes, à l'usage des astronomes et des navigateurs, pour l'an 1954. Ref. 411.

Desgl. für 1955. Ref. 411.

284. Ephémérides Nautiques ou extrait de la Connaissance des Temps pour l'an 1954. Ref. 427.

285. Annuaire pour l'an 1954. Ref. 446.

Philadelphia

286. Publications of the University of Pennsylvania. Astronomical Series.

8: F. B. Wood, A finding list for observers of eclipsing variables. Ref. 11212.

Posen. Siehe Poznań.

Potsdam

287. Publikationen des Astrophysikalischen Observatoriums zu Potsdam.

294 (97): W. Grotrian, Polaritäten und Maximalwerte magnetischer Feldstärken von Sonnenflecken in den Jahren 1946-1951. Ref. 6320.

288. Mitteilungen des Astrophysikalischen Observatoriums Potsdam.

Nr. 35: W. Mattig, Die radiale Verteilung der magnetischen Feldstärke in normalen Sonnenflecken. Ref. 6340.

36: U. Güntzel-Lingner, Graphisches Hilfsverfahren zur genäherten Bahnbestimmung visueller Doppelsterne nebst Anwendung auf das System ADS 7307. Ref. 10105.

37: U. Güntzel-Lingner, Die Bahn des Doppelsternsystems ADS 8148. Ref. 10106.

38: E. H. Schröter, Ein Versuch zur Bestimmung des Verlaufes der magnetischen Feldstärke über die Fläche eines Sonnenfleckes. Ref. 6358.

\section{Poznań (Posen)}

289. Poznań Observatory Reprints.

Nr. 28: J. Dobrzycki, The definite orbit of comet 1914e (Campbell). Ref. 8136.

29: J. Witkowski, Oppenheim's phenomenon and its bearing on the origin of comets. Ref. 8035 .

30: H. Hurnik, Occultations of stars by the moon. Ref. 7360 .

31: J. Dobrzycki, Observations of minor planets made at the Poznań University Observatory with the Zeiss astrograph ( $\varnothing=$ $120 \mathrm{~mm}, \mathrm{f}=53 \mathrm{~cm})$ in 1950 - 1951 . Ref. 7536 . 


\section{Pretoria}

290. Communications from the Radcliffe Observatory, Pretoria.

Nr. 21: A. D. Thackeray, Identifications in the spectra of Eta Carinae and RR Telescopii. Ref. 111109.

A. D. Thackeray, Note on the brightening of Eta Carinae. Ref. 11318.

22-24: Nicht eingegangen.

25: A. J. Wesselink, Radial velocity observations and the parallax of $\alpha$ Centauri. Ref. 10122.

26: $M$. W. Feast, The absolute magnitude and spectrum of the class S star $\pi^{1}$ Gruis. Ref. 9518.

291. Radcliffe Observatory Reprint.

Nr. 1: A. D. Thackeray, A. J. Wesselink, Distances of the Magellanic Clouds. Ref. 12433.

\section{Princeton}

292. Contributions from the Princeton University Observatory.

Nr. 23: J. E. Merrill, Tables for solution of light curves of eclipsing binaries. Coefficient of limb-darkening $x=1.0$. Ref. 11121 .

J. E. Merrill, Tables for solution of light curves of eclipsing binaries. Auxiliary tables. Ref. 11122.

24: J.E. Merrill, Nomographs for solution of light curves of eclipsing binaries. Ref. 11123.

\section{Pulkowo}

293. Mitteilungen (Iswestija) des Astronomischen Hauptobservatoriums Pulkowo. 193 (150): A. A. Michajlow, Utber die allergünstigsten Projektionen für Sternkarten. Ref. 9129.

A. N. Deutsoh, W. W. Lawdowskij, N. W. Fatsohichin, N. W. Gamalej, Ausgewählte Felder mit außergalaktischen Nebeln zum Anschluß von Eigenbewegungen der Sterne. Ref. 12406.

W. A. Jelistratow, Über die Untersuchung von Kreisen nach der Rosettenmethode. Ref. 2505.

W. A. Jelistratow, J.E. Gordon, Untersuchung der Teilungsfehler des Pulkowoer Meridiankreises. Ref. 2506.

B. A. Orlow, Ưber den Einfluß der Biegung auf die Ableitung eines absoluten Deklinationssystems. Ref. 2508.

W. M. Wassiljew, Neubearbeitung der Längenbeobachtungen von Pulkowo. Ref. 13229.

W. W. Lawdowskij, Genaue Orter des Planeten Pluto aus photographischen Beobachtungen in Pulkowo. Ref. 7809.

N. W. Fatschichin, Bestimmung der genauen Örter der Kleinen Planeten (39) Laetitia im Jahre 1950 und (6) Hebe in den Jahren 1950-1951. Ref. 7536.

S. W. Romanskaja, W. I. Sacharow, Vorläufige Werte der Breitenveränderung von Pulkowo von 1950.8 bis 1951.8. Ref. 13225.

4 (151): A. W. Sofronizkij, Utber die physikalische Natur der Unterriesen in engen Bedeckungsveränderlichen. Ref. 11133.

A. W. Markow, D. E. Schtschegolow, Über die mögliche Periodizität der Helligkeitsveränderung der Halbschattenmondfinsternisse. Ref. 7343.

L. A. Mitrofanowa, Bestimmung relativer gf-Werte des FeII. Ref. 231 . 
T. W. Krat, Die Photometrie astronomischer Negative im Falle sehr hoher Bildstärken. Ref. 2224.

N. N. Michelson, Ein selbstregistrierendes Kompensationsisophotometer. Ref. 1236.

N. N. Michelson, Der Einfluß der Verschiebung eines Negativs auf die Genauigkeit der photometrischen Messung. Ref. 2507.

294. Akademie der Wissenschaften der UdSSR und Astronomisches Hauptobservatorium Pulkowo.

A. A. Michajlow, Die Sonnenfinsternis am 30. Juni 1954 in der UdSSR. Ref. 6213.

\section{Richmond Hill}

295. Communications from the David Dunlap Observatory, University of Toronto.

Nr. 31: R. J. Northcott, Note on HD 201626, a new high-velocity R-type star. Ref. 9226.

32: J. F. Heard, The spectrum of Nova Scuti 1949. Ref. 11342.

33: W. R. Hossack, An oscilloscopic microphotometer for use with astronomical spectrograms. Ref. 2221.

34: H. B. Sa w yer, Thirty-eight new variable stars in eleven globular clusters. Ref. 12139.

\section{Rio de Janeiro}

296. Almanaque Náutico para 1954. Ref. 413.

\section{Riverview}

297. Riverview College Observatory. Reprint.

Nr. 4: D. J. K. O'Connell, Father Edward Francis Pigot, S. J. Ref. 1028.

5: D. O'Connell, «According to Hoyle». Ref. 5417.

\section{Roma}

298. Osservatorio Astronomico Roma Monte Mario. Contributi Scientifici.

Nr. 182: G. Armellini, La nuova torre solare dell'Osservatorio astronomico di Roma. Ref. 1238.

183: G. Armellini Conti, Posizioni di pianeti e pianetini ed occultazioni lunari osservate nel 1952 . $\$ 73,74,75,76,77,78$.

184: M. Cimino, T. Fortini, Area, posizione eliografica e classifica delle macchie solari durante l'anno 1952 , secondo i rilievi fotografici giomalieri dell'Osservatorio Astronomico di Roma (Monte Mario). Ref. 6370.

185: L. Gialanella, Osservazioni meridiane dell' ascensione retta di Mercurio e Venere nel 1952. Ref. 7101, 7116.

186: M. Cimino, Sulla variazione del profilo di alcune righe spettrali dal centro al lembo del Sole. III. Ref. 6403.

187: M. Cimino, T. Fortini, Fotometria fotografica dell'eclisse totale di luna del 29 gennaio 1953 e la luminescenza del suolo lunare per la radiazione ultravioletta solare. Ref. 7351.

188: M. Cimino, Sulla variazione del profilo di alcune righe spettrali dal centro al lembo del Sole. IV. Ref. 6404.

189: M. Cimino, Sulle soluzioni dell'equazione generale del potenziale newtoniano di una sfera fluida in equilibrio. Ref. 103.

190: M. A. Giannuzzi, Riduzione delle osservazioni dei diametri solari orizzontali, osservati a Greenwich, dal 1851 al 1937 e conferma dell'oscillazione con periodo di 23 anni trovata al Campidoglio. Ref. 6005 . 
191: G. Armellini, Osservazioni sul problema dei due corpi di masse variabili e sopra alcune sue applicazioni alla cosmogonia. Ref. 5404.

192: M. Cimino, Sull'equilibrio stellare convettivo in condizioni politropiche generalizzate. Ref. 5203.

193: M. Cimino, Il magnetismo stellare e i movimenti lenti della materia solare. Ref. 6120.

194: T. Fortini, Miglioramento delle orbite di cinque piccoli pianeti. Ref. 7536.

195: M. Cimino, Sulla variazione del profilo di alcune righe spettrali dal centro al lembo del Sỏle. V. Ref. 6405.

196: M. Cimino, Le variazioni del diametro solare osservate all'Osservatorio Astronomico di Roma e le recenti teorie elettrodinamiche stellari. Ref. 6004.

197: M. Cimino, Osservazioni della forma della corona e dei raggi coronali nell'eclisse totale di Sole del 25 febbraio 1952. Ref. 6210.

198: T. Fortini, Nuova determinazione della latitudine dell'Osservatorio di Monte Mario e confronto con i risultati ottenuti precedentemente da altri osservatori. Ref. 1238.

199: M. Poy, Orbita definitiva del pianetino 1196 Sheba. Ref. 7536.

200: G. Armellini, Sopra le variazioni dell'eccentricità nel problema astronomico dei due corpi di masse decrescenti. Ref. 4203.

\section{San Fernando}

299. Instituto y Observatorio de Marina de San Fernando. Sección de Astronomía. Serie B.

Nr. 1: Pequeños planetas. Ref. 7502.

300. Almanaque Nautico año 1954. Ref. 414.

301. Almanaque Nautico para uso de los navegantes año 1954. Ref. 429.

\section{Sendai}

302. Sendai Astronomiaj Raportoj.

218 (30): H. Nariai, On some linear equivalence in kinematic relativity. Ref. 4154.

19 (31): S. Kikuchi, Stellar dynamical meanings of Schürer's transformation. Ref. 4402.

20 (32): K. Suda, On the rotation problem of completely degenerate stellar configurations. Ref. 4308.

21 (33): K. Takakubo, An interpretation of interstellar gas clouds. Ref. 12521.

22 (34): Y. Hosokawa, On the rotation effect of velocity curves in eclipsing binary systems. Ref. 11108.

23 (35): Z. Hitotuyanagi, On the intensity formula of absorption lines. Ref. 5114.

24 (36): H. Nariai, Some remarks on Jordan's projective relativity. Ref. 4155.

\section{Sonneberg}

303. Mitteilungen der Sternwarte zu Sonneberg.

Nr. 41: C. Hoffmeister, Drei mehrfach beobachtete Meteore. Vgl. AJB 51 Ref. 8227.

C. Hoffmeister, Utber die «Leuchtenden Nachtwolken». Vgl. AJB 52 Ref. 72168. 
42: C. Hoffmeister, Das Problem des Ursprungs der Kometen. 1. Teil. Vgl. AJB 51 Ref. 8011.

C. Hoffmeister, Das Problem des Ursprungs der Kometen. 2. Tëil. Vgl. AJB 52 Ref. 8008.

43: N. Richter, Kometen - ein kosmischer Auflösungsprozeß. Ref. 8026.

E. Ahnert, Strahlungsdruck, Poynting-Robertson-Effekt und interplanetare Materie. Ref. 201.

W. Götz, Die Schmidtkamera der Sternwarte Sonneberg. Ref. 1241.

304. Mitteilungen über veränderliche Sterne. Nr. 161-166. §112.

\section{Stalinabad}

305. Bulletin des Astronomischen Observatoriums Stalinabad.

Nr. 7: O. W. Dobrowolskij, Zur Theorie der Kometenformen. Teil 2. Ref. 8009.

A. M. Bacharew, G. E. Jerlexowa, Beobachtungen der to. talen Mondfinsternis vom 29.-30. Januar 1953. Ref. 7351.

G. E. Jerlexowa, Der Bedeckungsveränderliche CC Hercules. Ref. 11216.

8: O. W. Dobrowolskij, Zur Theorie der Kometenformen. Teil 3. Ref. 8010.

A. M. Bacharew, Uber die Fehler bei der Beobachtung von Telemeteoren. Ref. 2501.

A. W. Solow jow, Ưber den Bedeckungsveränderlichen TY Capricorni. Ref. 11216.

\section{St. Andrews}

306. Reprints from the Observatory. University of St. Andrews.

Nr. 4: E. Finlay-Freundlich, Uber die Rotverschiebung der Spektrallinien. Ref. 4122.

5: Vgl. AJB 52.

6: Nicht eingegangen.

7-8: Vgl. AJB 52.

9: E. Finlay-Freundlich, Der heutige Stand der empirischen Bestätigung der allgemeinen Relativitätstheorie. Ref. 4123.

10: E. Finlay-Freundlich, University Observatory, St. Andrews. Ref. 1101.

11: Nicht eingegangen.

12: E. Finlay-Freundlich, Emanuel von der Pahlen †. Ref. 1001.

\section{Stockholm}

307. Stockholms Observatoriums Annaler.

17 5: G. Larsson-Leander, A spectrographic and spectrophotometric study of 31 Cygni at the eclipse in 1951. Ref. 11118.

6: B. Lindblad, R. G. Langebartel, On the dynamics of stellar systems. Ref. 4406.

7: J. M. Ramberg, The distribution of light in the corona of the eclipse of 1914 August 21. II. Ref. 6202 .

8: G. Larsson-Leander, The early post-maximum spectrum of Nova DK Lacertae (1950). Ref. 11330.

308. Stockholms Observatorium. Meddelande.

Nr. 75: Y. Ohman, N. E. Ohman, On a disturbance in a prominence probably initiated by a distant flare. Ref. 6634 . 
76: Y. Ohman, N. E. Ohman, On some solar observations made with an $\mathrm{H} \alpha$ monochromator. Ref. 6635.

77: B. Lindblad, H. Kristenson, Chromospherio and photospheric gradients from cinematography of the flash spectrum. Ref. 6628 .

78: Y. O hman; On some phenomena related to dark and bright prominences. Ref. 6633 .

309. Stockholms Observatoriums Arsberāttelse för året 1952. Ref. 1101.

\section{Swarthmore}

310. Reprints of articles published by the Sproul Observatory.

Nr. 80: S. L. Lippincott, Red dwarf flare stars. Ref. 11191.

81: P. van de Kamp, J. E. Damkoehler, Parallax and orbital motion of 61 Cygni from photographs taken with the 24-inch Sproul refractor. Ref. 9806.

P. van de Kamp, J. E. Damkoehter, Parallax and orbital motion of the multiple system $\sigma$ Coronae Borealis A, B, e from photographs taken with the 24 -inch Sproul refractor. Ref. 9306.

82: S. L. Lippincott, Parallaxes and proper motions of six nearby stars from photographs taken with the 24-inch Sproul refractor. Ref. 9306.

83: P. van de Kamp, Student observations of Delta Cephei. Ref. 11151 .

84: S. L. Lippincott, Parallax and orbital motion of Krüger 60. Ref. 9306.

85: S. L. Lippincott, Note on the light-curve of the flare-up of Krüger 60 B, 1939 July 26. Ref. 11192.

\section{Sydney}

311. Sydney Observatory. Astrographic Catalogue 1900.0.

34: Sydney Section R. A. $6^{\text {h }}$ to $12^{\text {h }}$, Dec. $-59^{\circ}$ to $-61^{\circ}$. Ref. 9121.

312. Sydney Observatory Papers.

Nr. 19: K. P. Sims, Occultations observed at Sydney Observatory during 1952. Ref. 7360 .

313. Commonwealth Scientific and Industrial Research Organization, Australia, Division of Radiophysics.

J. H. Piddington, Thermal theories of the high-intensity components of solar radio-frequency radiation. Ref. 6529 .

R. N. Bracewell, The sunspot number series. Ref. 6306.

J. H. Piddington, R. D. Davies, Origin of the solar corona. Ref. 6721.

W. N. Christiansen, J. A. Warburton, The distribution of radio brightness over the solar disk at a wavelength of 21 centimetres. I. A new highly directional aerial system. Ref. 6516.

W. N. Christiansen, A high-resolution aerial for radio astronomy. Ref. 2108.

F. J. Kerr, Radio astronomy at the URSI assembly. Ref. 12621. W. N. Christiansen, J. A. Warburton, The distribution of radio brightness over the solar disk at a wavelength of 21 centimetres. II. The quiet sun - one-dimensional observations. Ref. 6517. 
B. Y. Mills, A. G. Little, A high-resolution aerial system of a new type. Ref. 2127.

J. H. Piddington, Theories of solar phenomena depending on sunspot fields moving in the chromosphere and corona. Ref. 6350. J. L. Pawsey, Radio astronomy in Australia. Ref. 12631.

R. Bracewell, A new instrument in radio astronomy. Ref. 1244. J. P. Wild, J. D. Murray, W. C. Rowe, Evidence of harmonics in the spectrum of a solar radio outburst. Ref. 6534 .

J. G. Bolton, O. B. Slee, Galactic radiation at radio frequencies. V. The sea interferometer. Ref. 12604.

J. G. Bolton, O. B. Slee, G. J. Stanley, Galactic radiation at radio frequencies. VI. Low altitude scintillations of the discrete sources. Ref. 12605 .

B. Y. Mills, The radio brightness distributions over four discrete sources of cosmic noise. Ref. 12627.

E. G. Bowen, The influence of meteoritic dust on rainfall. Ref. 8301 .

E. G. Bowen, Radiophysics Laboratory, Sydney. Ref. 1101.

A. P. Mitra, C. A. Shain, The measurement of ionospheric absorption using observations of $18.3 \mathrm{Mc} / \mathrm{s}$ cosmic radio noise. Ref. 7287.

J. P. Wild, Techniques for observation of radio-frequency radiation from the sun. Vgl. Ref. 6015.

J. L. Pawsey, S. F. Smerd, Solar radio emission. Vgl. Ref. 6015 .

J. H. Pidding ton, R. D. Davies, Thermal radio emission from the sun and the source of coronal heating. Ref. 6720 .

Tacubaya. Siehe Tonantzintla.

\section{Tartu (Dorpat)}

314. Publikationen (Publikazii) des Astronomischen Observatoriums Tartu.

32 5: A. J. Kipper, Utber die Entstehung der Magnetfelder der Sterne. Ref. 9807.

A. J. Kipper, Uber das kontinuierliche Spektrum der galaktischen Nebel. Ref. 12221.

G. G. K usmin, Das dritte Integral der Sternbewegung und die Dynamik der stationären Galaxis. Ref. 4403.

\section{Taschkent}

315. Publikationen (Trudy) des Astronomischen Observatoriums Taschkent.

(2) 3: P. A. Sawizkij, Untersuchung der Eigenbewegungen von Sternen im Gebiet des offenen Sternhaufens NGC 6885. Ref. 12118. P. P. Loginow, Über die Reduktionen von Meridianbeobachtungen. Ref. 2411.

J. M. Slonim, Die Sonnentätigkeit 1946. Ref. 6370, 6651.

P. P. Loginow, Ưber die innere Ausgleichung des Deklinationssystems von Sternpaaren aus Beobachtungen mit dem Zenitteleskop. Ref. 2412.

J. M. Slonim, Die Sonnentätigkeit 1947. Ref. 6370, 6651.

316. Zirkular des Astronomischen Observatoriums Taschkent. Nr. 250-267. Ref. 2334, 6370, 6651 .

Thorn. Siehe Torún. 


\section{Tokyo}

317. Annals of the Tokyo Astronomical Observatory, University of Tokyo.

(2) 3 3: S.-Y. Obi, T. Ishidzu, H. Horie, S. Yanagawa, Y. Tanabe, M. Sato, Tables of the Racah coefficients W (abcd; ef). I. Coefficients having all their variables integral. Ref. 113.

4: S. Iijima, Y. Katou, S. Okazaki, J. Matsumoto, Improvement of the JJC time signal. Ref. 2907.

S. Iijima, Quartz crystal clocks in Tokyo. Ref. 2308.

S. Iijima, Y. Katou, J. Matsumoto, N. Kouno, New equipments for clock comparison. Ref. 2309.

M. Huruhata, Photoelectric studies of the night sky light. Ref. 72110.

T. Nakamura, H. Tanabe, Photoelectric observations of RU Eridani. Ref. 11125.

M. Notsuki, S. Nagasawa, I. Shimizu, A thallium-lamp photometer for the coronal observation. Ref. 1228.

$H$. Yasuda, The measurement of instrumental errors of a meridian instrument by an interferometer. Ref. 2520 .

B. Takase, On the stability of the binary system in the fluctuating density field of the interstellar matter. Ref. 10009.

T. Takenouchi, Preliminary report on the photoelectric observations of eclipses of Jupiter's satellites. Ref. $\mathbf{7 6 3 0}$.

K. Tuzi, The general aspect of the observation made with the Repsold transit instrument in Tokyo Astronomical Observatory. Ref. 9117.

H. Hirose, On the prediction of the equal-limb-line for an occultation. Ref. 3202.

K. Saito, Spectroscopic observations of the solar corona at the total solar eclipse on September 21, 1941. Ref. 6204.

M. Huruhata, T. Dambara, M. Kitamura, A photoelectric study of YY Eridani. Ref. 11109.

T. Hatanaka, A solution for the path of radio waves through the solar atmosphere by elliptic integrals. Ref. 6524.

318. Tokyo Astronomical Bulletin. Second Series.

Nr. 53: K. Tuzi, Meridian observation of right ascension of equatorial stars made with Repsold transit instrument. Preliminary result No. 2. Ref. 9118.

54: F. Arata, Y. Hirai, H. Kurai, Occultation observations in Japan during 1951. Ref. 7360.

55: M. Torao, Star list for the photographic zenith tube at the Tokyo Astronomical Observatory. Ref. 9115.

56: S. Nakano, R. Fukaya, Meridian observations of the right ascension of minor planets during the year 1952. Ref. 7512.

57: H. Hirose, K. Tomita, Photographic observations made with the Brashear astrograph $(30)$. $\$ 75,78,81$.

58: M. Notuki, Preliminary result of the coronal observation at Mt. Norikura. Ref. 6735.

59: S. Nakano, H. Yasuda, R. Fukaya, H. Hara, Meridian observations of the right ascensions of the Moon and planets during the year 1952. Ref. 7101, 7116, 7301, 7401, 7601, 7701, 7801, 7805.

60: K. Tuzi, Meridian observation of right ascension of equatorial stars made with Repsold transit instrument. Preliminary result No. 3. Ref. 9118.

61: S. Fujii, Preliminary determination of right ascension of P.Z.T. stars for Tokyo. Ref. 9105. 
62: K. Tuzi, Meridian observation of right ascension of equatorial stars made with Repsold transit instrument. Preliminary result No. 4. Ref. 9118.

63: S. Habara, Y. Otoguro, An annular eclipse of the sun, April 19, 1958. Ref. 6214.

319. Tokyo Astronomical Observatory Reprints.

Nr. 104: T. Hatanaka, F. Moriyama, A note on the long-period variation in the radio-frequency radiation from the quiet sun. Ref. 6525 .

105: Y. Kozai, Preliminary studies on the motion of asteroid Thule (279) II. Ref. 7509.

106: K. Aoki, Observation of the partial solar eclipse (February 14, 1953) at the wave-length of 10 centimeters (3000 megacycles). Ref. 6212.

107: N. Sekiguchi, Analysis of the nutation terms of the fortnight period using the international latitude observations. Ref. 3110.

108: M. Huruhata, M. Kitamura, A photoelectric study of RZ Tauri. Ref. 11110.

320. Tokyo Astronomical Observatory. Bulletin of Solar Phenomena.

4 4: October-December, 1952. Ref. 6370, 6536, 6651.

5 1-3: January-September 1953. Ref. 6370; 6536, 6651.

Maritime Safety Agency.

321. Japanese Ephemeris 1954. Ref. 415.

322. Nautical Almanac 1954. Ref. 416.

323. Abridged Nautical Almanac 1954. Ref. 429a.

Tonantzintla y Tacubaya

324. Boletin de los Observatorios Tonantzintla y Tacubaya.

Nr. 6: P. Pișmiș, La dinamica de un sistema doble de cumulos y el cumulo dóble en Perseo. Ref. 12115.

R. Toscano, Determinacion de la hora por medio de un par de estrellas observadas a diferentes alturas sin que entre como dato la latitud. Ref. 2329.

7: Graciela González, Guillermina González, Lista de estrellas de alta luminosidad. Ref. 9704.

G. Haro, A. Moreno, Estrellas con $\mathrm{H} \alpha$ en emision en las cercanias de IC 434 . Ref. 9525.

L. Münch, Estrellas "OB» y a de alta luminosidad en Cefeo. Ref. 9713.

8: G. Haro, B. Iriarte, E. Chavira, Nuevas estrellas con emision en las regiones obscuras del Toro-Auriga-Orion investigadas por Joy. Ref. 9526.

L. Münch, W. W. Morgan, Estrellas gigantes azules en las cercanias de Eta Carinae. Ref. 9714.

L. Münch, Estrellas de alta luminosidad entre Vela y Cruz. Ref. 9715.

\section{Torino}

(325). Contributi dell'Osservatorio Astronomico di Torino (Pino Torinese). Nuova Serie.

Nr. 18: N. Missana, Osservazioni di latitudine fatte alla seconda sala meridiana dell'Osservatorio Astronomico di Torino dal 6 settembre 1943 al 4 gennaio 1947. Ref. 1246. 
19: N. Missana, Correzioni delle orbite dei piccoli pianeti 1551 e 1552. \& 75 .

20: N. Missana, Osservazione dell'eclisse di Sole del $1^{\circ}$ settembre 1951. Ref. 6209.

21: Nicht eingegangen.

22: A. Fresa, Curva di luce della variabile ad eclisse XX Cephei. Ref. 11104.

23: A. Fresa, La variazione della latitudine dell'Osservatorio di Pino Torinese (I. Sala meridiana) e la verifica della legge Hattori. Ref. 13207.

(326). Studi Monografici. Prima Serie.

Nr. 1: P. Tempesti, Le popolazioni stellari di Baade. Ref. 12004.

(327). Ufficio Centrale delle latitudini dell'U. A. I. - Osservatorio Astronomico di Torino (Pino Torinese). Pubblicazioni.

Nr. 1: G. Cecchini, Declinazioni apparenti delle copie di stelle osservate nelle Stazioni Internazionali di Latitudine - Parallelo Nord. 1950. Ref. 13202.

2: G. Cecchini, Variazioni delle latitudini terrestri e fenomeni geofisici. Vgl. AJB 50 Ref. 13202.

3: G. Cecchini, Le variazioni di latitudine e il movimento del polo di rotazione terrestre in base alle osservazioni fatte nelle Stazioni Internazionali di Latitudine dal gennaio 1949 all' aprile 1950. Vgl. AJB 50 Ref. 13201.

4: G. Cecchini, Declinazioni apparenti delle copie di stelle osservate nelle Stazione Internazionali di Latitudine - Parallelo Nord. 1951. Ref. 13202.

5: G. Cecchini, Le variazioni di latitudine e il movimento del polo di rotazione terrestre in base alle osservazioni fatte nelle Stazioni Internazionali di Latitudine nel biennio 1949-1950. Vgl. AJB 51 Ref. 13203.

6: G. Cecchini, Declinazioni apparenti delle copie di stelle osservate nelle Stazioni Internazionali di Latitudine - Parallelo Nord. 1952. Ref. 13202.

7: G. Cecchini, Relazione sull'attività del Servizio Internazionale delle Latitudini dal 1949.0 al 1952.5 presentata alla Commissione della Variazione delle Latitudini (VIII Assemblea generale dell'U. A. I. Roma, 4-13 settembre 1952). Ref. 13003.

8: G. Cecchini, Declinazioni apparenti delle copie di stelle osservate nelle Stazioni Internazionali di Latitudine - Parallelo Nord. 1953. Ref. 13202.

9: G. Cecchini, Declinazioni apparenti delle copie di stelle osservate nelle Stazioni Internazionali di Latitudine - Parallelo Nord. 1954. Ref. 13202.

10: G. Cecohini, Rapport sur l'activité du Bureau Central du Service International des Latitudes du ler novembre 1952 au 30 octobre 1953. Ref. 13002.

\section{Tortosa}

328. Boletín del Observatorio del Ebro.

38: Heliofísica 1950. Ref. 6370.

\section{Toruń (Thorn)}

329. Bulletin of the Astronomical Observatory of N. Copernicus University in Torun. 
Nr. 11: W. Iwanowska, A spectrophotometric study of RR Lyrae type variables. Ref. 11149 .

H. Tomasik, An attempt at establishing a colour temperature scale for some high velocity stars form the slope of their photographic energy curves. Ref. 9604.

C. Łubieńska-Iwaniszewska, Some physical and kinematical properties of the RR Lyrae type variables. Ref. 11155.

12: W. Dziewulski, Motions of high velocity stars. II. Ref. 12328. W. Dziewulski, On the determination of vertices from the peculiar motions of subdwarfs. Ref. 12329. I

T. Rakowiecki, Formules pour le calcul de l'orbite et de l'éphéméride d'une binaire visuelle. Ref. 10120.

W. Dziew ulski, Photographic observations of the short period variable UZ Leonis. Ref. 11216.

W. Dziewulski, Photographic observations of the short-period variable TV Leonis. Ref. 11216.

W. Dziewulski, Photographic observations of the short-period variable RY Comae. Ref. 11216.

W. Dziew ulski, Photographic observations of the variable star SV Vulpeculae. Ref. 11216.

W. Dziewulski, Visual observations of the variable star $\mathrm{XZ}$ Draconis. Ref. 11216.

W. Dziew ulski, Visual observations of the long-period variable star $\chi$ Cygni. Ref. 11216.

\section{Toulouse}

330. Observatoire de l'Université de Toulouse. Rapport annuel 1950-1951. Ref. 1101.

\section{Trieste}

331. Osservatorio Astronomico di Trieste.

Nr. 251: Annuario Astronomico per l'anno 1954 con le carte del cielo. Ref. 453.

252: Atti del Convegno degli Astrofili veneti tenuto a Treviso domenica 18 settembre 1949 . Ref. 11106.

253: A. Abrami, Letteratura sulla Polodia preceduta da un esposto storico esplicativo del problema. Ref. 707.

254: B. Cester, Osservazioni di stelle doppie. Ref. 10128.

\section{Tübingen}

332. Mitteilungen des Astronomischen Instituts der Universität Tübingen.

Nr. 6: H. Siedentopf, G. Elwert, Radiofrequenzemission von Ultrastrahlungselektronen. Ref. 12643.

7: A. Behr, H. Siedentopf, Untersuchungen über Zodiakallicht und Gegenschein nach lichtelektrischen Messungen auf dem Jungfraujoch. Ref. 8404.

8: G. Elwert, Über die Bedeutung einer weichen Röntgenstrahlung der Sonnenkorona für die Bildung der normalen ionosphärischen E-Schicht. Ref. 6707.

9: Vgl. AJB 54.

10: H. Siedentopf, Radioastronomie. II. Beobachtungsergebnisse über kosmische Radioquellen. Ref. 12641.

11: Vgl. AJB 54.

12: Vgl. AJB 54. 
13: H. Siedentopf, A. Behr, H. Elsässer, Photoelectric observations of the zodiacal light. Ref. 8411.

\section{Uecle}

333. Annales de l'Observatoire Royal de Belgique. Troisième Série.

6 3: J. Dommanget, Méthode empirique systématique d'amélioration des éléments orbitaux d'une étoile double visuelle. Ref. 10104.

J. Dommanget, Orbites des étoiles doubles visuelles ADS $16326=\mathrm{BDS} 12025=\mathrm{A} 632$ et $\operatorname{ADS} 17178=\operatorname{BDS} 12696=$ Hn 60. Ref. 10131.

J. Dommanget, Droites et coniques déterminées par la méthode des moindres carrés. Ref. 104.

334. Bulletin Astronomique de l'Observatoire Royal de Belgique à Uccle.

4 7: S. Arend, F. Rigaux, A. Schmitt, Observations photographiques de petites planètes, de Neptune et de comètes, faites en 1952 à l'astrographe double de $40 \mathrm{~cm}$. Ref. 7536, 7805, § 81 .

S. Arend, A. Schmitt, Observations photographiques de petites planètes et de comètes, faites on 1953 (1er semestre) à l'astrographe double de $40 \mathrm{~cm}$. Ref. 7536, § 81 .

S. Arend, L. Neven, J. Dommanget, Occultations d'étoiles observées à l'équatorial de $45 \mathrm{~cm}$ pendant la période $1942-1952$. Ref. 7360 .

J. Dommanget, Orbite de l'étoile double visuelle: $\operatorname{ADS} 5447=$ BDS $3601=0 \Sigma 156$. Ref. 10131 .

S. Arend, Orbite de l'étoile double visuelle: ADS $7307=$ BDS $5030=\Sigma 1338$. Ref. 10131 .

S. Arend, Orbite de l'étoile double visuelle: ADS $9019=$ BDS $6619=\Sigma$ 1781. Ref. 10131.

S. Arend, Orbite de l'étoile double visuelle: ADS $16057=$ BDS $11828=\Sigma 2924$. Ref. 10131 .

335. Communications de l'Observatoire Royal de Belgique.

49: J. Hunaerts, Interprétation du spectre d'émission de $\mathrm{OH}$ dans les comètes. Ref. 8015.

50: Vgl. AJB 52 Ref. 13220.

51: Vgl. AJB 52 Ref. 111126.

52: E. Vandekerkhove, Tables et graphiques concernant les fonctions de Planck, Stefan et Wien. Ref. 242.

53: G. Coutrez, Observations des taches solaires en 1952. Ref. 6370.

54: J. Hunaerts, La Nova Scuti 1952 (Arend). Vgl. AJB 52 Ref. 11339.

55: M. Castellano, P. J. Melchior, Sur un effet systématique dans l'enregistrement photographique de la position des graduations d'un cercle méridien. Vgl. AJB 52 Ref. 2502.

56: M. Migeotte, L. Neven, High-dispersion solar spectrograms between $15 \mu$ and $24 \mu$. Vgl. AJB 52 Ref. 6416.

M. Migeotte, L. Neven, E. Vigroux, Structure fine de la bande d'absorption de l'ozone à $9.6 \mu$ observée dans le spectre solaire et en laboratoire. Vgl. AJB 52 Ref. 7245.

E. Vigroux, M. Migeotte, L. Neven, Etude, à grande dispersion, des bandes d'absorption de l'ozone à $9 \mu, 4.75 \mu, 3.59 \mu$ et $3.27 \mu$. Ref. 7259 .

E. Vigroux, M. Migeotte, L. Neven, Largeurs équivalentes des bandes d'ozone à $9.6 \mu, 4.75 \mu$ et $3.27 \mu$. Ref. 7260 . 
57: P. Bourgeois, Rapport sur les travaux scientifiques effectués pendant l'année 1952. Ref. 1101.

58: D. de Smet-de Potter, M. Neyts, Etude spectrophotométrique et statistique d'une région obscure dans Cassiopée. Ref. 12519.

59: P. J. Melchior, Astronomia meridiana e Geofisica. Ref. 13217.

60: R. Coutrez, A. Koeckelenbergh, E. Pourbaix, Observations radioastronomiques de l'éclipse solaire du 25 février 1952. Ref. 6210.

61: E. Vandekerkhove, Une méthode spectrophotométrique de détermination des rayons stellaires. Ref. 9724.

62: J. Dommanget, La recherche de systèmes planétaires inconnus. Ref. 10002.

63: S. Arend, Paraboles de degré n passant par $n+1$ points dont les abscisses procèdent par intervalle constant. Ref. 101.

64: Vgl. AJB 54.

65: W. Benesch, M. Migeotte, L. Neven, Investigations of atmospheric $\mathrm{CO}$ at the Jungfraujoch. Ref. 7233.

336. Observations des taches solaires. Rotation 1327-1338. Ref. 6370.

\section{Uppsala}

337. Uppsala Astronomiska Observatoriums Annaler.

3 8: B. Westerlund, Luminosity effects and colour-equivalents as measured in short stellar spectra. II. F, G, and $\mathrm{K}$ stars. Ref. 9573.

9: C. Schalén, Theoretical investigations on reflection nebulae. Ref. 5323.

10: B. Westerlund, Luminosity effects and colour-equivalents as measured in short stellar spectra. III. Summary of classification criteria. Investigation of the region of the open cluster in Coma Berenices. Ref. 9574.

Utrecht

338. Sterrewacht «Sonnenborgh» Utrecht. Overdruk.

Nr. 1: M. G. J. Minnaert, De Utrechtse Sterrewacht en har geschiedenis 1642-1853-1953. Ref. 1249.

2: C. de Jager, The structure of the metal meteorites and the problem of their origin. Ref. 8309.

3: C. de Jager, De ouderdom van de meteorenregen uit Perseus. Ref. 8261.

4: F. J. Dannenburg, De helderheden der planeten. Ref. 7007.

5: M. G. J. Minnaert, A search for temperature differences between the poles and the equator of the sun. Ref. 6418 .

6: M. G. Minnaert, Discorso di M. G. J. Minnaert a nome dei partecipanti stranieri. Ref. 11109.

7: J. Houtgast, Gradients of line strengths in the chromosphere. Ref. 6621.

8: J. Houtgast, A high or a low kinetic temperature in the reversing layer of the sun? Ref. 6411 .

9: J. Houtgast, J. Damen Sterck, Orde in de zonneverschijnselen, anno 1953. Ref. 6006 .

\section{Victoria}

339. Publicatons of the Dominion Astrophysical Observatory Victoria, B. C.

9 7: A. B. Underhill, The shell star 14 Comae. Ref. 9571. 
8: R. M. Petrie, Absolute magnitudes of the B stars determined from measured intensities of the $\mathrm{H} \gamma$ line. Ref. 9718.

9: J.K. McDonald, Hydrogen absorption lines in the spectra of B-type stars. Ref. 9538.

10: R. M. Petrie, Wave-length standards for radial-velocity determinations from B-type spectra. Ref. 9222.

340. Contributions from the Dominion Astrophysical Observatory Victoria, B. C.

Nr. 28: A. McKellar, J. L. Climenhaga, A comparison of observed and calculated intensity profiles for the $\mathrm{C}_{2}$ Swan bands in cometary spectra. Ref. 8020 .

29: Vgl. AJB 52 Ref. 11120.

30: A. B. Underhill, The relative abundance of hydrogen to helium in stars. Ref. $\mathbf{5 1 3 9}$.

31: R. M. Petrie, B. N. Moyls, Convergent point and space motion of the Ursa, Major cluster. Ref. 12336.

32: A. B. Underhill, On the problem of the $\mathrm{H} \alpha$ ennission in the shell stars. Ref. 9570.

33: P. Swings, A. McKellar, K. Narahari Rao, Spectra of the late $\mathrm{N}$-type stars in the ultra-violet, violet and blue-green regions. Ref. 9567.

\section{Washington}

341. Astronomical Papers prepared for the use of the American Ephemeris and Nautical Almanac.

13 4: G. M. Clemence, Coordinates of the center of mass of the Sun and the five outer planets $1800-2060$. Ref. 7005 .

15 1: E. W. Woolard, Theory of the rotation of the Earth around its center of mass. Ref. 4310.

2: H. G. Hertz, The mass of Saturn and the motion of Jupiter 1884-1948. Ref. 7605.

342. Publications of the United States Naval Observatory. Second Series.

17 2: U. S. Lyons, L. R. Wylie, Observations of double stars made with the 26-inch equatorial of the U.S. Naval Observatory 1945-48. Ref. 10128.

3: A. Hall jr., H. E. Burton, U. S. Lyons, L. R. Wylie, G. M. Raynsford, W. M. Browne, J. L. Smith, Observations of satellites made with the 26 -inch equatorial of the U. S. Naval Observatory $1928-47$. Ref. 7012.

343. United States Naval Observatory Circular.

Nr. 41: W. Sawtell, Positions, areas, and counts of sunspots September-December 1952. Ref. 6370.

42: Solar summary for 1952. Ref. 6370 .

43-46: W. Sawtell, Positions, areas, and counts of sunspots JanuaryOctober 1953. Ref. 6370.

344. Smithsonian Institution. Publication.

4112: J. A. Ratcliffe, Radio Astronomy. Ref. 12632.

4113: L. O. Colbert, The sun, the moon, and the tides. Ref. 4202.

4131 : C. G. Abbot, Long-range effects of the sun's variation on the temperature of Washington, D. C. Ref. 6801.

4135: C. G. Abbot, Solar radiation, a leading weather element. Ref. 6802.

345. Annual Report for 1952. Ref. 1101. 


\section{Wellington}

346. Carter Observatory. Astronomical Bulletin.

Nr. 38: Public sessions programme and astronomical data for 1953. Ref. 1251.

39: Report of the Carter Observatory Board for the year ended 1953, March 31. Ref. 1101.

40: Public sessions programme and astronomical data for 1954. Ref. 1251 .

347. Carter Observatory. Reprint.

Nr. 19: K. D. Adams, P. A. Read, Visual observations of Mars in 1952. Ref. 7402 .

\section{Wendelstein}

348. Forschungsberichte der Kommission Observatorium Wendelstein der Bayerischen Akademie der Wissenschaften.

Nr. 6: R. Müller, tלber die Rotation der inneren Korona. Ref. 6717.

7: R. Müller, Katalog monochromatischer Koronastrahlen 1952. Ref. 6735.

8: A. Güttler, Über die Ost-West-Asymmetrie der Filamentbeobachtungen. Ref. 6620 .

9: W. Kraul, Absolutanschluß der grünen Koronalinie $\lambda=5303 \mathrm{~A}$ an die Sonnenmitte. Ref. 6713.

Wien

349. Mitteilungen der Universitäts-Sternwarte Wien.

6 6: J. Hopmann, Das System ADS $12345=$ J 116. Vgl. AJB 52 Ref. 10123.

7: K. Ferrari d'Occhieppo, Zur Deutung einer antiken Entstehungstheorie der Milchstraße. Ref. 1309.

8: J. Hopmann, Photometrie von 420 visuellen Doppelsternen. Ref. 10109.

9: G. Schrutka-Rechtenstamm, Definitive Bahnbestimmung des Kometen 1930 III (Wilk). Vgl. AJB 52 Ref. 8126.

350. Mitteilungen der Universitäts-Sternwarte Wien. J. Hopmann, Bericht über die Jahre 1945-1952. Ref. 1101.

\section{Wrochaw (Breslau)}

351. Communications from the Wrockaw Astronomical Observatory.

Nr. 1: S. Ninger-Kosibowa, Estimates of ten new variable stars in Centaurus. Ref. 11209.

2: S. Ninger-Kosibowa, The corrected elements of SY Aurigae. Ref. 11216.

3: S. Ninger-Kosibowa, The determination of the photovisual extinction. Ref. 7267.

\section{Zürich}

352. Publikationen der Eidgenössischen Sternwarte Zürich.

10 2: M. Waldmeier, Heliographische Karten der Photosphäre für das Jahr 1952. Ref. 6370.

353. Astronomische Mitteilungen der Eidgenössischen Sternwarte Zürich.

Nr. 181: M. Waldmeier, Synthese der Sonnenkorona. Ref. 6732. 
182: M. Waldmeier, Die Randverdunkelung der radiofrequenten Sonnenstrahlung bei $\lambda=10.7 \mathrm{~cm}$. Ref. 6533 .

183: M. Waldmeier, Die Sonnenfinsternis-Expedition der Schweizerischen Naturforschenden Gesellschaft. Ref. 6210.

184: M. Waldmeier, Die Sonnenaktivität im Jahre 1952. Ref. 6370, $6651,6735$.

354. Quarterly Bulletin on Solar Activity Nr. 97-100. Ref. 6370, 6536, 6651, 6735.

355. Tätigkeitsbericht der Eidgenössischen Sternwarte Zürich für das Jahr 1952. Ref. 1101. 